Historic, archived document

Do not assume content reflects current scientific knowledge, policies, or practices. 
- 


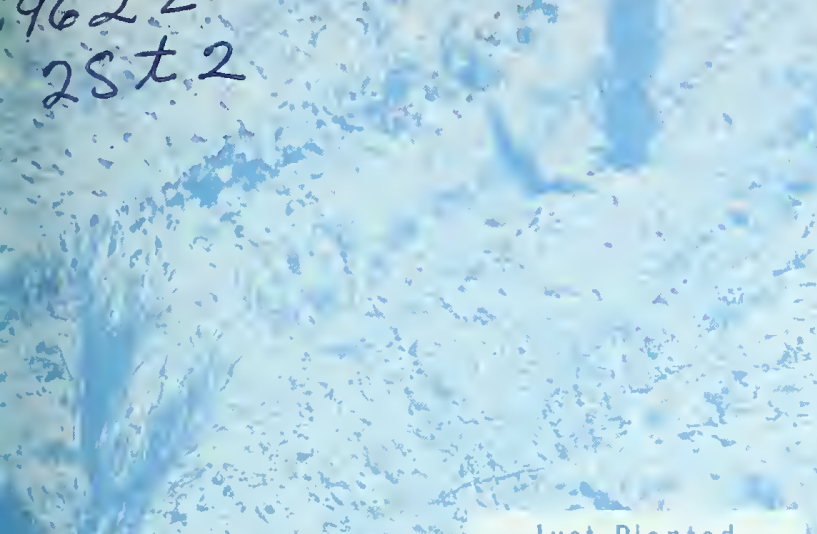

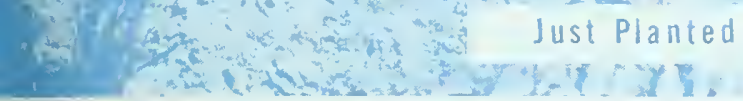

U. S. DEPT OF AGR!CULTURE

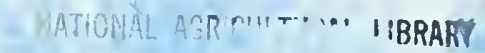

NOV 291962

CURREIII SERIAL RECOROS

\section{FOREST PLANTATIONS}

of NORTHERN

LOWER MICHIGANY

Robert N.Lstone,

Clarence D. Chase

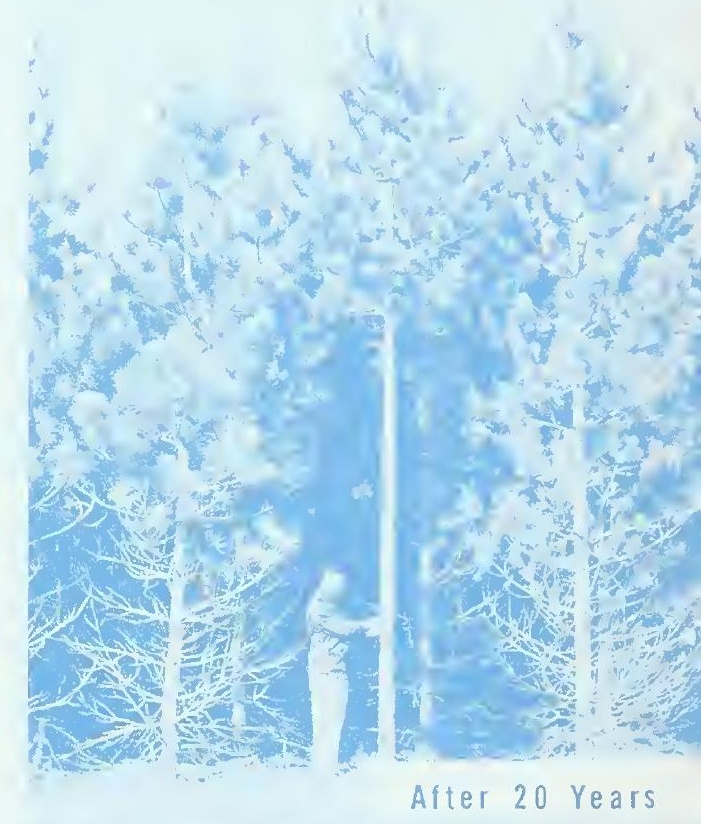

Ta LAKE STATES FOREST EXPERIMENT STATION。 $+7 b$ M. B. Dickerman, Director

7 (U.S.FOREST SERVICE, + $7 a$

U. S. DEPARTMENT OF AGRICULTURE

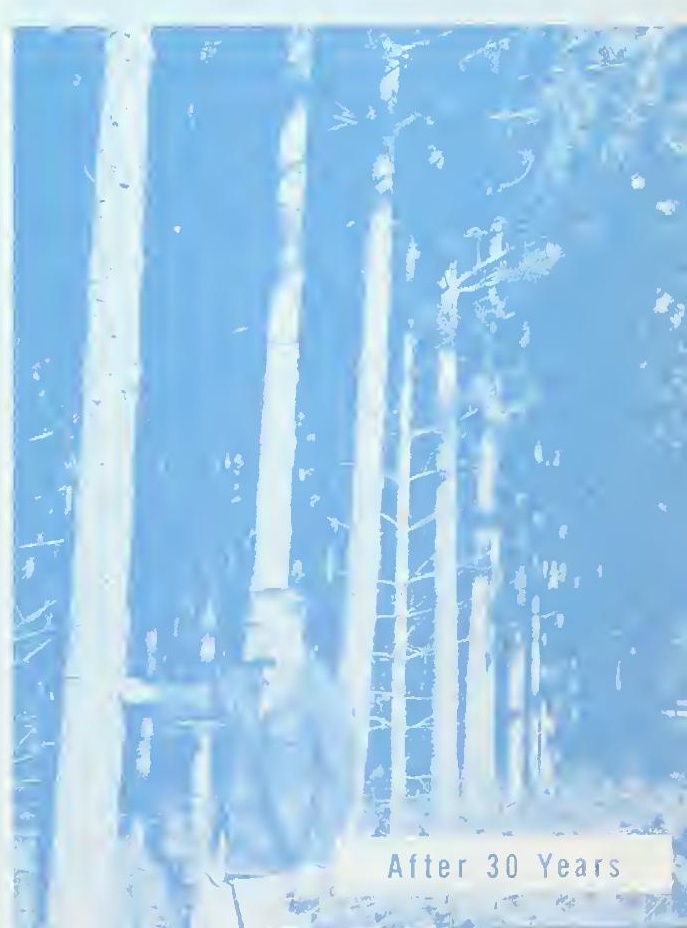




\section{ACKNOWLEDGMENTS}

This report is based on data collected by the Lake States Forest Experiment Station, members of cooperating public agencies, and the Consumers Power Company. The authors are indebted and grateful to all who helped.

The individuals and organizations collecting and supplying plantation field data were the Lower Michigan National Forest, Michigan Department of Conservation, and Consumers Power Company. Special acknowledgment is made to Edward F. Totton, Consumers Power Company; Uno Marttila, Lower Michigan National Forest; and Ray Pfeifer, Michigan Department of Conservation, for their efforts in directing the survey of their organizations' plantings.

An initial part of the survey was summarizing tree shipments to private planters throughout the study area. Valuable assistance was extended by F. J. Hodge, State Forest Nurseries, Michigan Department of Conservation; Ira Bull, Chief Nurseryman, Michigan State University; and Frank Monroe, Area Forester, U. S. Soil Conservation Service.

During the field sampling of private plantations a number of county clerks and treasurers, Extension Service agents, and Soil Conservation Service personnel were helpful in locating the tree shipment recipients. 


\section{CONTENTS}

Page

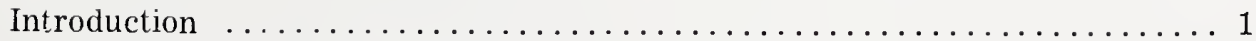

Half a century of planting $\ldots \ldots \ldots \ldots \ldots \ldots \ldots \ldots \ldots \ldots \ldots \ldots$

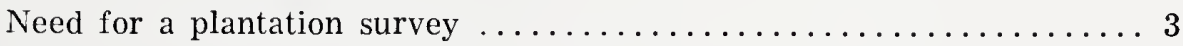

Survey objectives $\ldots \ldots \ldots \ldots \ldots \ldots \ldots \ldots \ldots \ldots \ldots \ldots \ldots \ldots$

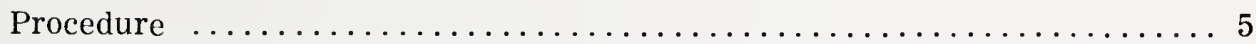

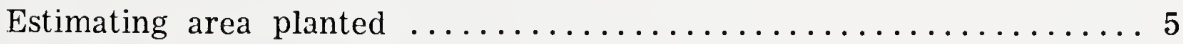

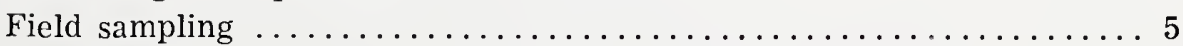

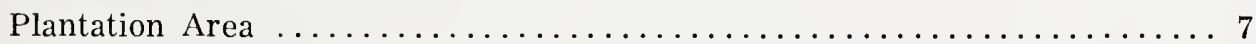

Nearly two-thirds of a million acres planted $\ldots \ldots \ldots \ldots \ldots \ldots \ldots \ldots$

Four-fifths of the plantings successfully established $\ldots \ldots \ldots \ldots \ldots \ldots 10$

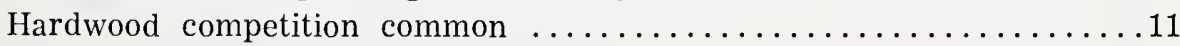

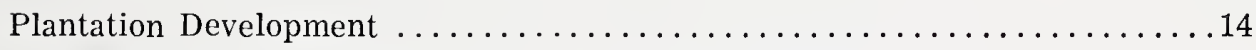

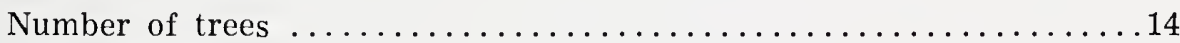

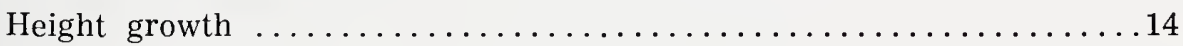

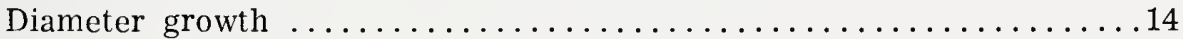

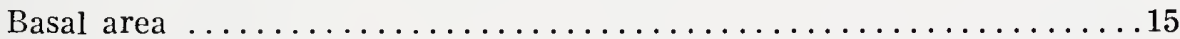

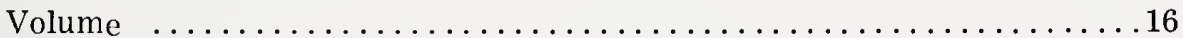

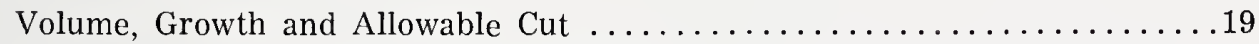

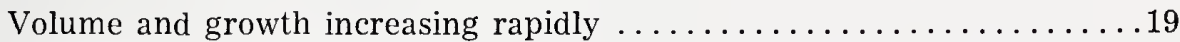

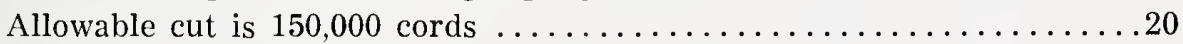

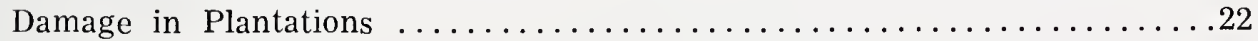

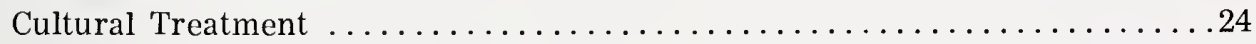

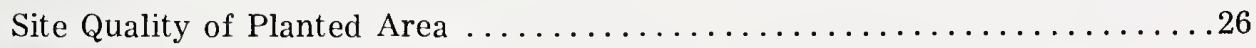

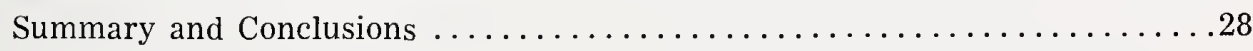

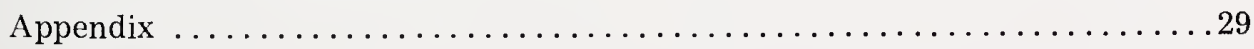

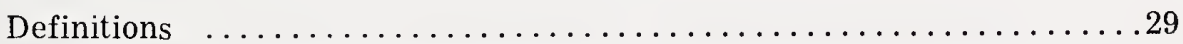

Method used to determine allowable cut in plantations from 1957-1966 ..29

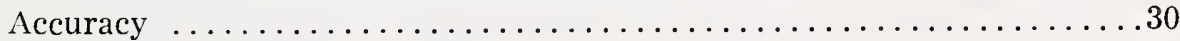




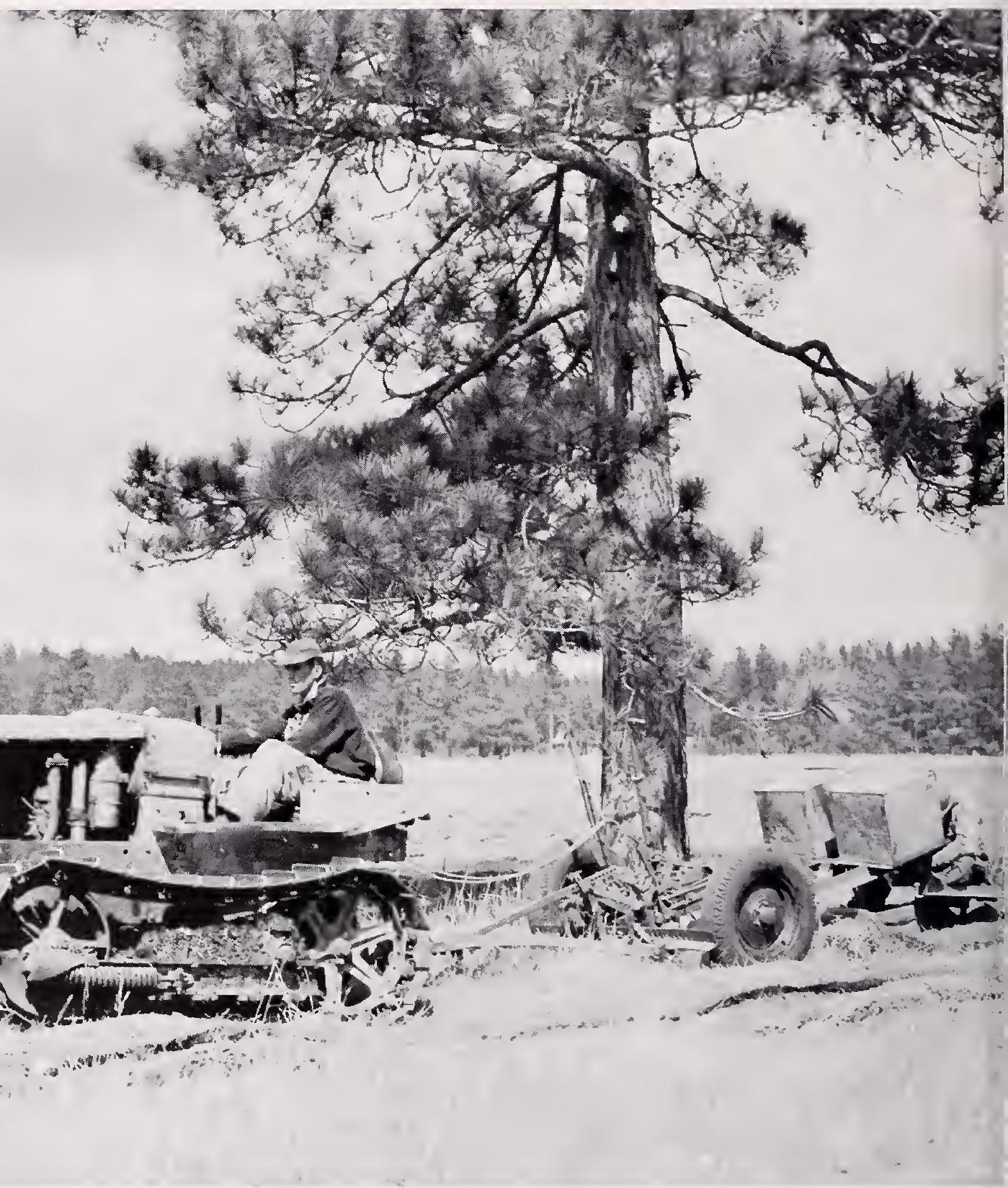

Figure 1. - Michigan has planted over $1 \frac{11 / 4}{4}$ million acres to trees.

(Photo courtesy of Consumers Power Company.) 


\section{- INTRODUCTION}

Michigan, long a leader in reforestation, completed the planting of 1 million acres of trees in 1955. It was the first State to achieve that distinction. In 1957 Michigan ranked ninth nationally in the area planted to forest trees that year, 56,000 acres; only the Southern States and Oregon exceeded that figure (fig. 1). ${ }^{1}$

During the last Statewide Forest Survey completed in $1956,2,870,000$ acres of nonstocked Forest land were classed as plantable. Although the original conifer forests covered an estimated 18 million acres, only 4 million acres are now in softwood types. Much of the land originally in conifers is stocked with hardwoods, but nonstocked forest land is common in many parts of the State.

Much of Michigan's presettlement pine forest grew in northern Lower Michigan. After the relatively light sandy soils in this region lost their tree cover and were scorched by fires, native restocking was sparse. Because of the obvious need for reforestation in the northern Lower Peninsula, this area received most of the early tree planting.

\section{Half a Century of Planting}

As early as 1880 small test plantings were made in Iosco and Oscoda Counties. ${ }^{2}$ However, reforestation probably began near Higgins Lake with small plantings on the State forests about 1904. Early forest plantings were largely on State land and were generally on a small scale until about the end of World War 1.

Through the early twenties reforestation was confined almost exclusively to public land, predominantly State lands; private plantings consisted of small blocks or windbreaks. Toward the end of the twenties several thousand acres were being planted annually.

During the Great Depression of the thirties, the Civilian Conservation Corps proved to be the program with the greatest impact on reforestation

1 U.S. Forest Service. Report of forest and windbarbarrier planting undertaken in the United States, July 1, 1956-June 30,195\%, $18 \mathrm{pp} .195 \%$.

2 Rudolf, Paul O. Forest plantations in the Lake States, U. S. Dept. Agr. Tech. Bul. 1010, 171 pp., illus. 1950. (fig. 2). Through the thirties reforestation increased rapidly and accomplishments were measured in tens of thousands of acres annually. In less than 10 years more than a quarter of a million acres were planted in northern Lower Michigan.

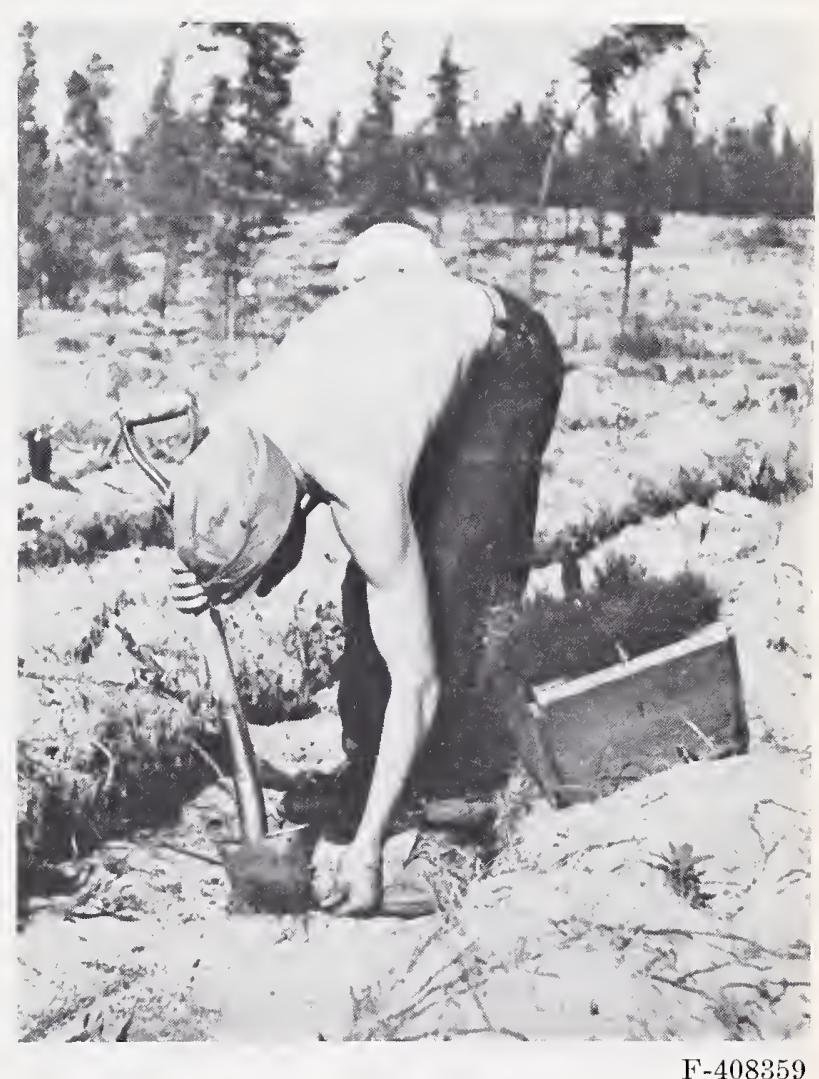

Figure 2. - The depression-born Civilian Conservation Corps put thousands of unemployed youths to work. During this program over 250,000 acres were planted to trees in northern Lower Michigan.

The widespread planting activity on public forests awakened the interest of private landowners. County Agricultural Agents, Extension Service Foresters, Soil Conservation Service technicians, and State Foresters encouraged tree planting told groups how to plant, where to plant, and how to get planting stock. The U. S. Department of Agriculture, through its Clark-McNary Program, assisted the State College in providing trees at reasonable rates. Tree planting became a common spring and fall activity although achievements, until the late thirties, were largely on public land. 

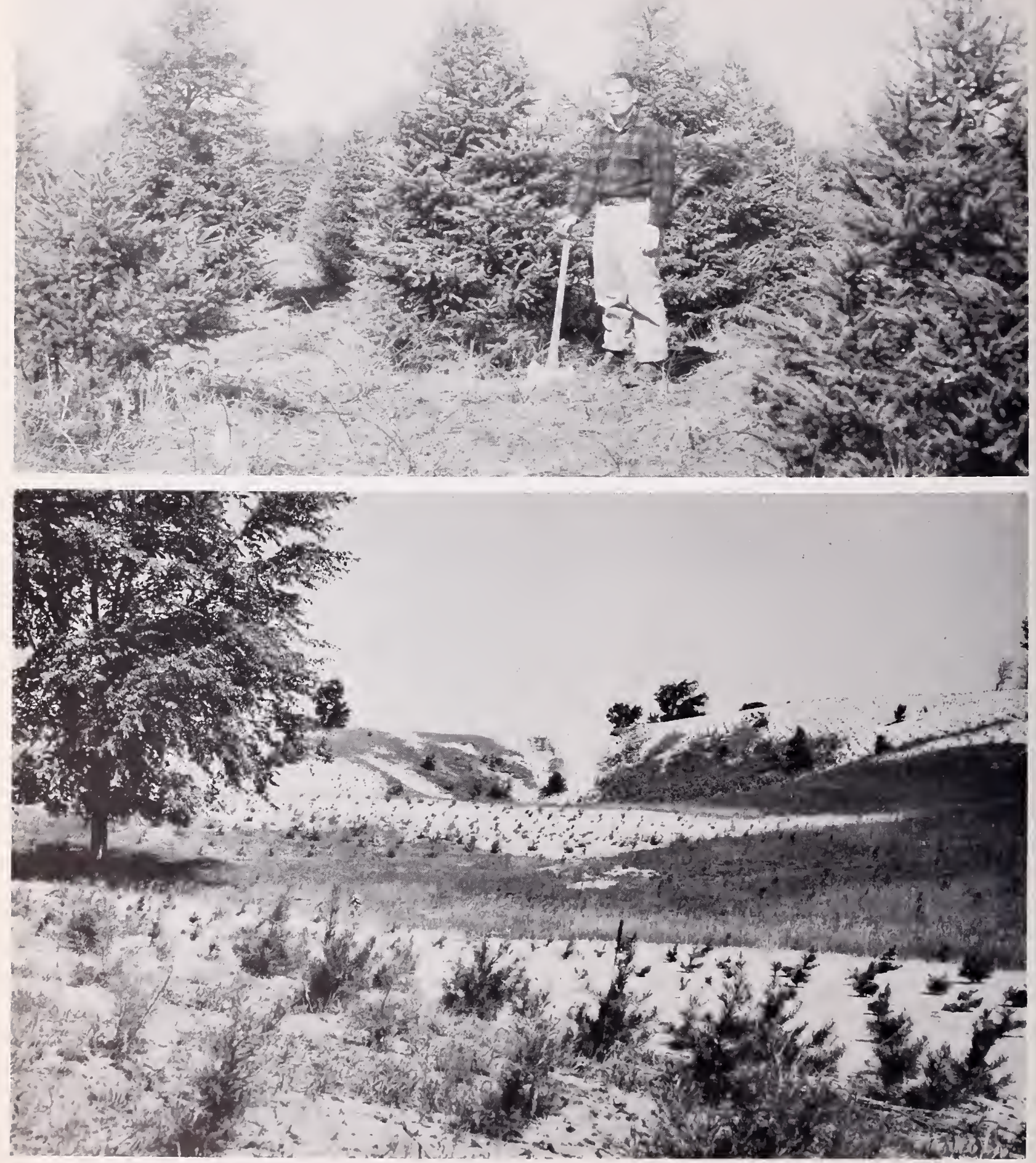

FiguRE 3. - Trees were planted for many reasons besides timber production; two were Christmas tree production(above) and erosion control (below'). 
The purpose of planting trees varied with different landowners but revolved around putting idle land into use (fig. 3 ). On public land the reason was mainly to reestablish forest cover. In addition, students planted school forests while studying conservation, and road departments planted trees to provide living snow fences. On private land farmers planted to stop sheet erosion. Power companies planted to protect their reservoirs and watersheds, and summer home owners planted to make their vacation spots more attractive.

By 1940 private planting amounted to just over 7 percent of the acreage planted. Public planting, therefore, can be expected to produce most early yields of timber products.

World War II curtailed large-scale tree planting, and reforestation on State and National Forests almost stopped. The low rate of planting on private lands remained constant. This situation prevailed until 1946.

During the war two new factors arose that were to have an important influence on tree planting. The first was the rapid acceptance of pine, particularly Scotch and red pine, as commercial Christmas trees; the demand for plantation Christmas trees exceeded the available supply in the forties. The second factor was the development of a practical tree-planting machine capable of planting about 1,000 trees per hour. These two developments supplied the motive and means for increasing private planting. Following the war, planting stock was in short supply, and nursery production was accelerated both by the public nurseries and by the rapidly expanding private tree nursery industry (fig. 4). Annual acreage planted on public forests stayed well below the peaks reached during the thirties, but private planting expanded rapidly in the late forties as supplies of planting stock improved.

In northern Lower Michigan private planting made up more than three-fourths of the planting in the early fifties. Private planting differed from public planting in two respects: (1) Scotch pine, red pine, and spruce were more heavily planted and there was less emphasis on white and jack pine; and ( 2 ) better sites on open fields (former cropland) were planted, which increased the State's forest area.

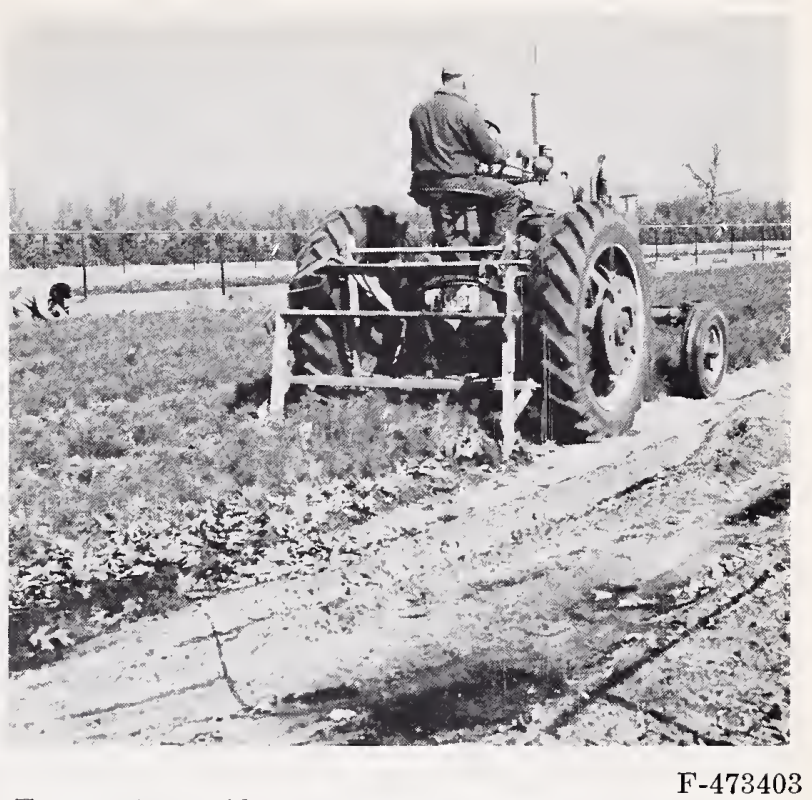

Frgure 4. - About 160 tree nurseries are producing planting stock in Michigan for tree planters.

\section{Need For A Plantation Survey}

By the mid-fifties there was an increasing demand for information about the area of established plantations, their location, condition, and possible yields. Many of the earliest plantations had reached poletimber-size, and increasing acreages were entering that size annually. Cuts were beginning in older plantings, although they were mainly a few scattered experimental thinnings and harvests of Christmas trees. It was apparent that sizable commercial thinnings in plantations could begin soon. Although estimates of the acreage planted had been made from time to time and complete records were available for plantings made on public lands, these data presented only what had been done and revealed little of the actual field condition of the plantings. The two Forest Surveys made in the State included planted acreage, but they were not designed to pinpoint plantation areas or to separate them from the native pine types. Furthermore, the market situation was changing rapidly. Mill expansion in the fifties had increased the demand for conifer pulpwood in Lower Michigan. Part of the expanding mill capacity was made on the assumption that plantations would provide part of future wood requirements.

Rough acreage estimates were not good enough to answer the requests for specific information about plantations. The need for a plantation sur- 
vey to get detailed data on area, volume, growth, and expected yields became evident. In late 1956 planning for a survey of plantations began.

\section{Survey Objectives}

As with any Forest Survey, the study objectives were numerous. The specific objectives of the plantation survey were to determine by forest type:

1. How many acres had been planted in each county and how many had become "established?"
2. What was the volume of planted trees?

3. What was the extent and influence of native tree overstories?

4. How do volume, height, and basal area change with age?

5. How serious has been the damage from various causes?

6. How many acres have had stand improvement measures, and how many need them?

7. What is the site index of plantations?

8. What are the expected yields? 
The survey area included 34 counties in northern Lower Michigan (fig. 5 ). The Lake States Forest Experiment Station headed the project. Three major cooperators sampled their own plantings Lower Michigan National Forest, the Michigan Department of Conservation, and the Consumers Power Company. The job was divided into two parts: The first was determining the planted acreage; the second, sampling the plantings on the ground to get estimates of established acres and obtain volume, growth, and overstory information.

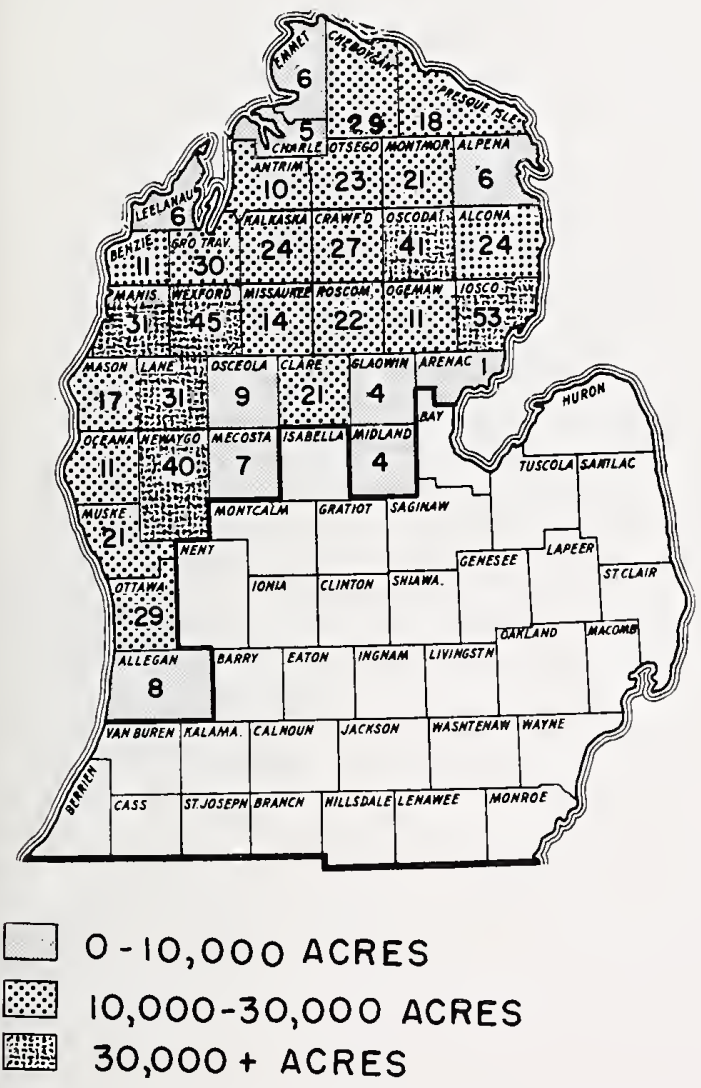

Figure 5. - Forest plantings by county, 1900-56. The figures within each county indicate total area planted in thousands of acres.

\section{Estimating Area Planted}

The area planted on public land and large industrial holdings was summarized from planting records by species, decade planted, and county.

Determining area planted by other private owners was much more difficult. The first step was to

\section{- Procedure}

summarize numbers of trees shipped directly to the owners from public nurseries, or distributed by the Soil Conservation Service. Trees in lots of 500 trees or more were totaled by county, decade planted, and species. Assuming one acre was planted with each thousand trees shipped, this record provided an estimate of the planted area and served as the basis for selecting and allocating the field sample.

\section{Field Sampling}

The field sample was allocated for each ownership group. The number of samples depended primarily on the number needed to give desired statistical accuracy for the entire acreage (proportionally more samples were measured by cooperators who wanted reliable data for their own plantings). The basic allocation was weighted by age (decade planted) as shown below to insure that an adequate sample would be obtained in older plantings where small acreages were involved as well as where earliest yields could be expected:

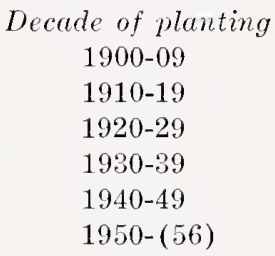

Sampling weight

The total sample was then allocated by planted type and decade on the basis of the weighted acreage.

Plots were allocated independently for the four ownership classes. The mechanics of selecting the sample varied somewhat, depending on the way records were kept, availability of aerial photos, etc.

Once a sample planting (or tree shipment) was selected, its size determined how many plots were to be measured in it.

To balance the sample in large and small plantings the number of plots measured in a sample plantation was varied as follows: 
Plantation size

1 - 9 acres

10 - 39 acres

$40-159$ acres

$160-319$ acres

$320+$ acres
Number of plots allocated 1

2

3

4

5

Field samples consisted of 1/50-acre circular plots. All planted trees were tallied by 1 -inch classes. In the northeast quadrant of each plot every tree was measured for total height, merchantable height to $3,4,6$, and 8 inches diameter inside bark, and d.b.h. to one-tenth inch. Site index was estimated on each plot having an undamaged, dominant, planted tree over 15 feet tall. Each plot was classified by forest type, stand-size, and density class, using Forest Survey standards. The ba-

sal area of native trees was measured with an angle gauge. All field information was recorded on a prepared plot-tally sheet.

Each plot was laid out with a radius cord fastened at the plot center. Heights were measured with jointed bamboo rods except for the tallest trees for which Abney levels or similar tools were used. Diameters were measured with tapes for the sample trees and by ocular estimates with occasional tape checks for the remaining trees. The distances between plots were paced and the direction determined with hand compasses.

Damage to planted trees was recorded and the causal agent indicated, and a record was made of past and needed silvicultural treatment. 


\section{Nearly Two-Thirds of a Million Acres Planted}

This survey found that forest plantings cover about two-thirds of a million acres in northern Lower Michigan. Acreages planted are about evenly divided among National Forest, State Forest, and private lands, although early plantings were nearly all public. In recent years more acreage has been planted on private land than on public.

From 1900 to 1920 fewer than 8,000 acres were planted in the 34 counties. This was increased by more than 71,000 acres during the twenties (fig. 6 ).

Nearly 275,000 acres were planted during the thirties, 93 percent on public land. During the forties, because of the diversion of men and materials to the war effort, only 70,000 acres were planted on public land. A shortage of planting stock hampered all planting in the late forties, but the rate of planting on private land began a phenomenal rise. This upward trend continued through the fifties. Three-fourths of all planting from 1950 to 1956 occurred on private lands; these efforts were spurred on by the expectation of strong Christmas

\section{- plantation area}

tree markets, speculation in recreational land, and changes in land use. Planting on public forests from 1950 to 1956 stabilized at the 1940 to 1949 level, with a small decline on National Forest land offset by an increase on State Forest land. The following tabulation summarizes the acreage planted by decade on all ownerships:

$\begin{array}{rrr}\text { Period } & \text { Acres planted } & \text { Percent of total } \\ 1900-19 & 7,500 & 1.1 \\ 1920-29 & 71,120 & 10.8 \\ 1930-39 & 274,290 & 41.5 \\ 1940-49 & 122,400 & 18.5 \\ 1950-56 & 185,280 & 28.1 \\ \text { Total } & 660,590 & 100.0\end{array}$

On the National Forests more than one-half of the trees planted were red pine in pure stands, while on State Forests 60 percent of the plantings were a mixture of red and jack pine (table 1 ). Less than one-half of one percent of all public plantings were spruce. About half of the plantings on private lands are red pine and one-fifth are Scotch pine.

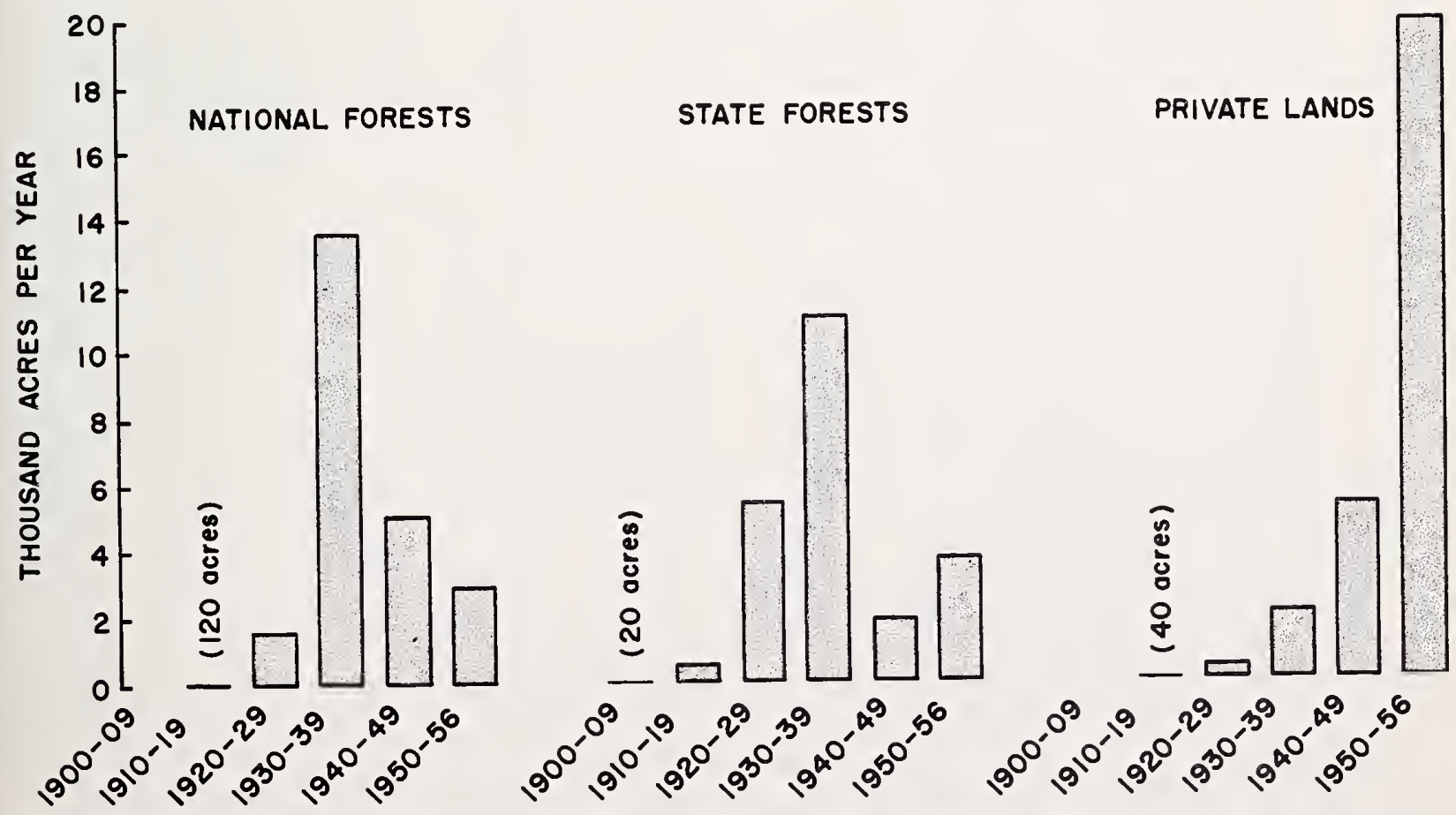

Figure 6. - Planting trends in northern Lower Michigan by owner, 1900-1956. 
TABle 1. - Forest plantings in Northern Lower Michigan by owner, species group, and decade. (In acres)

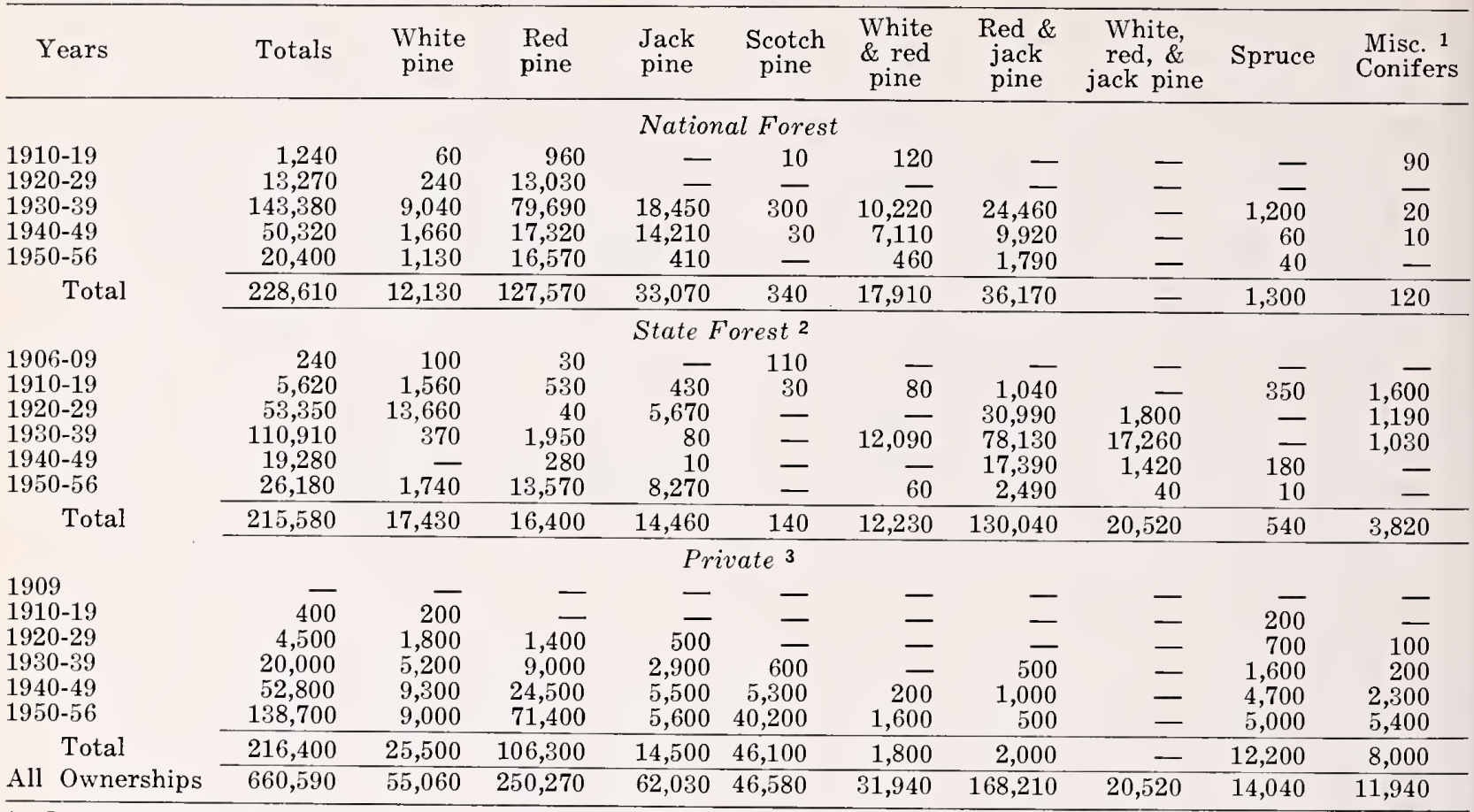

1 Includes miscellaneous conifers such as ponderosa pine,pitch pine, Austrian pine, Douglas-fir, balsam fir, European larch, and a small acreage of unusual mixtures. Hardwood plantings are not included.

2 Excludes state forest plantings in Allegan County, records for which are not available.

3 Estimated from shipment summaries of public nurseries on the basis of one thousand trees per acre. Shipments of fewer than 500 trees are not included. Includes plantings on county and school forests and other small public holdings.

The most extensively planted species is red pine, which accounts for 250,000 acres. Next in importance are mixed plantings of red and jack pine, which were commonly planted on public lands this combination covers a quarter of the area planted or more than four times the area planted to pure jack pine. Although eastern white pine has decreased in popularity because of the twin hazards of blister rust and white-pine weevil, it still ranks as the third most planted species. A phenomenal rise in the rate of planting Scotch pine has occurred during the last decade, almost entirely on private land. The planting of hardwoods in forest plantations has been negligible.

Tree planting in 6 of the 34 counties in the study area has exceeded 30,000 acres; in 10 counties less than 10,000 acres each have been planted. Although forest plantings vary widely by counties, some patterns are apparent (fig. 5 ). Counties with high public ownership of forest land tend to have large plantation areas (table 2). Where soils are relatively unproductive for general farming and idle land is common, the area planted is above average (table 3 ).

Generally, planting on private lands declines across the survey area from southwest to northeast. Ottawa County has the largest acreage of private plantings; it is closely followed by Muskegon County. An expanding Christmas tree industry in that area has strongly influenced tree planting rates. The major emphasis is on Scotch pine - a preferred Christmas tree - although many Austrian pine and white spruce are being planted.

The major planting effort is now concentrated in the western part of the survey area. The six counties with the highest planting rates during the early fifties are, in order of importance, Wexford, Ottawa, Benzie, Newayo, Missaukee, and Grand Traverse. 
TABLE 2. - Forest plantings in northern Lower Michigan by county and owner, 1900-56

(In acres)

\begin{tabular}{|c|c|c|c|c|c|c|c|c|c|}
\hline County & Total & $\begin{array}{c}\text { National } \\
\text { forest }\end{array}$ & $\begin{array}{l}\text { State } \\
\text { forest }\end{array}$ & $\underset{1}{\text { Private }}$ & County & Total & $\begin{array}{c}\text { National } \\
\text { forest }\end{array}$ & $\begin{array}{l}\text { State } \\
\text { forest }\end{array}$ & $\underset{1}{\text { Private }}$ \\
\hline Alcona & 23,540 & 20,640 & - & 2,900 & Mason & 17,480 & 10,680 & - & 6,800 \\
\hline Allegan & 7,800 & & 2 & 7,800 & Mecosta & 6,870 & 950 & 20 & 5,900 \\
\hline Alpena & 5,990 & - & 4,790 & 1,200 & Midland & 4,030 & - & 30 & 4,000 \\
\hline Antrim & 10,230 & - & 1,830 & 8,400 & Missaukee & 13,720 & - & 4,520 & 9,200 \\
\hline Arenac & 1,340 & - & 440 & 900 & Montmorency & 21,000 & - & 19,200 & 1,800 \\
\hline Benzie & 11,320 & - & 3,220 & 8,100 & Muskegon & 20,810 & 310 & - & 20,500 \\
\hline Charlevoix & 5,160 & - & 2,460 & 2,700 & Newaygo & 40,490 & 29,290 & - & 11,200 \\
\hline Cheboygan & 29,470 & - & 22,670 & 6,800 & Oceana & 11,200 & 5,800 & - & 5,400 \\
\hline Clare & 20,720 & - & 16,720 & 4,000 & Ogemaw & 11,050 & - & 9,750 & 1,300 \\
\hline Crawford & 26,890 & 4,650 & 21,040 & 1,200 & Osceola & 9,180 & - & 80 & 9,100 \\
\hline Emmet & 5,560 & - & 2,960 & 2,600 & Oscoda & 41,460 & 33,110 & 5,750 & 2,600 \\
\hline Gladwin & 4,420 & - & 2,420 & 2,000 & Otsego & 22,580 & - & 14,580 & 8,000 \\
\hline Grand Traverse & 29,760 & - & 18,760 & 11,000 & Ottawa & 28,700 & - & & 28,700 \\
\hline Iosco & 53,190 & 51,680 & 10 & 1,500 & Presque Isle & 17,770 & - & 16,270 & 1,500 \\
\hline Kalkaska & 24,120 & & 18,620 & 5,500 & Roscommon & 22,010 & & 21,610 & 400 \\
\hline Lake & 31,290 & 28,790 & 800 & 1,700 & Wexford & 45,360 & 24,130 & 5,030 & 16,200 \\
\hline $\begin{array}{l}\text { Leelanau } \\
\text { Manistee }\end{array}$ & $\begin{array}{r}5,540 \\
30,540\end{array}$ & 18,580 & $\begin{array}{r}540 \\
1,460\end{array}$ & $\begin{array}{r}5,000 \\
10,500\end{array}$ & Total & 660,590 & 228,610 & 215,580 & 216,400 \\
\hline
\end{tabular}

1 Estimated from shipment summaries of public nurseries on the basis of one thousand trees per acre. Shipments of fewer than 500 trees are not included. Includes plantings on county and school forests and

other small public holdings.

2 Excludes state forest plantings in Allegan County, for which records are not available.

TABLE 3. - Forest plantings in northern Lower Michigan by county and species group, 1950-56

(In acres)

\begin{tabular}{|c|c|c|c|c|c|c|c|c|c|c|}
\hline County & Totals & $\begin{array}{l}\text { White } \\
\text { pine }\end{array}$ & $\begin{array}{l}\text { Red } \\
\text { pine }\end{array}$ & $\begin{array}{l}\text { Jack } \\
\text { pine }\end{array}$ & $\begin{array}{l}\text { Scotch } \\
\text { pine }\end{array}$ & $\begin{array}{l}\text { White } \\
\text { \& red } \\
\text { pine }\end{array}$ & $\begin{array}{l}\text { Red \& } \\
\text { jack } \\
\text { pine }\end{array}$ & $\begin{array}{l}\text { White, } \\
\text { red, \& } \\
\text { jack pine }\end{array}$ & Spruce & $\begin{array}{l}\text { Misc. }{ }^{1} \\
\text { conifers }\end{array}$ \\
\hline Alcona & 23,540 & 650 & 12,600 & 3,000 & 300 & 280 & 6,530 & - & 160 & 20 \\
\hline Allegan & 27,800 & 950 & 2,110 & 830 & 2,490 & 10 & - & - & 990 & 420 \\
\hline Alpena & 5,990 & 1,700 & 460 & 110 & 260 & 1,120 & 1,670 & 30 & 250 & 390 \\
\hline Antrim & 10,230 & 900 & 4,050 & 1,340 & 3,020 & - & 320 & - & 340 & 260 \\
\hline Arenac & 1,340 & 50 & 780 & 300 & 130 & - & - & - & 50 & 30 \\
\hline Benzie & 11,320 & 1,210 & 5,760 & 1,860 & 1,630 & - & 390 & - & 290 & 180 \\
\hline Charlevoix & 5,160 & 1,600 & 1,570 & 700 & 100 & 40 & 590 & 320 & 160 & 80 \\
\hline Cheboygan & 29,470 & 3,500 & 4,990 & 500 & 570 & 1,510 & 12,240 & 4,910 & 240 & 1,010 \\
\hline Clare & 20,720 & 530 & 2,820 & 80 & 770 & - & 16,070 & 80 & 270 & 100 \\
\hline Crawford & 26,890 & 1,950 & 4,060 & 2,440 & 290 & 1,540 & 14,850 & 970 & 80 & 710 \\
\hline Emmet & 5,560 & 400 & 3,070 & 200 & 350 & 30 & 650 & 560 & 150 & 150 \\
\hline Gladwin & 4,420 & 230 & 1,060 & 490 & 100 & - & 700 & 1,460 & 350 & 30 \\
\hline Grand Traverse & 29,760 & 3,680 & 7,310 & 2,410 & 1,230 & 2,280 & 9,530 & 2,250 & 890 & 180 \\
\hline Iosco & 53,190 & 620 & 53,280 & 2,850 & 540 & 1,060 & 4,330 & - & 370 & 140 \\
\hline Kalkaska & 24,120 & 1,080 & 5,350 & 1,150 & 790 & 340 & 10,980 & 4,200 & 160 & 70 \\
\hline Lake & 31,290 & 2,360 & 11,850 & 6,110 & 90 & 3,940 & 6,800 & - & 80 & 60 \\
\hline Leelanau & 5,540 & 1,020 & 3,030 & 390 & 610 & - & 160 & - & 240 & 90 \\
\hline Manistee & 30,540 & 3,640 & 12,060 & 5,860 & 1,310 & 3,880 & 3,210 & - & 290 & 290 \\
\hline Mason & 17,480 & 1,080 & 7,100 & 2,460 & 1,760 & 1,680 & 2,880 & - & 300 & 220 \\
\hline Mecosta & 6,870 & 940 & 3,410 & 250 & 1,010 & 190 & 270 & - & 530 & 270 \\
\hline Midland & 4,030 & 880 & 1,580 & 780 & 450 & - & 10 & - & 200 & 130 \\
\hline Missaukee & 13,720 & 280 & 7,460 & 1,550 & 1,350 & - & 1,820 & 390 & 740 & 130 \\
\hline Montmorency & 21,000 & 960 & 1,940 & 1,740 & 360 & 990 & 14,460 & 350 & 140 & 60 \\
\hline Muskegon & 20,810 & 3,640 & 7,760 & 670 & 6,040 & - & - & - & 1,470 & 1,230 \\
\hline Newaygo & 40,490 & 5,230 & 15,350 & 3,190 & 2,650 & 5,210 & 7,450 & - & 370 & 1,040 \\
\hline Oceana & 11,200 & 1,950 & 6,380 & 970 & 560 & 400 & 20 & - & 550 & 370 \\
\hline Ogemaw & 11,050 & 1,290 & 850 & 600 & 170 & 450 & 6,500 & 650 & 100 & 440 \\
\hline Osceola & 9,180 & 500 & 6,050 & 520 & 1,530 & - & - & - & 250 & 330 \\
\hline Oscoda & 41,460 & 1,270 & 24,710 & 7,250 & 180 & 610 & 6,510 & 190 & 720 & 20 \\
\hline Otsego & 22,580 & 1,970 & 7,000 & 1,150 & 1,360 & 2,580 & 7,710 & 520 & 170 & 120 \\
\hline Ottawa & 28,700 & 3,540 & 7,500 & 2,190 & 11,830 & - & - & - & 1,970 & 1,670 \\
\hline Presque Isle & 17,770 & 740 & 850 & 350 & 570 & 1,090 & 13,220 & 440 & 170 & 340 \\
\hline Roscommon & 22,010 & 3,860 & 440 & 1,020 & 90 & 1,020 & 11,450 & 2,970 & 80 & 1,080 \\
\hline Wexford & 45,360 & 860 & 25,680 & 6,720 & 2,090 & 1,690 & 6,890 & 230 & 920 & 280 \\
\hline Total & 660,590 & 55,060 & 250,270 & 62,030 & 46,580 & 31,940 & 168,210 & 20,520 & 14,040 & 11,940 \\
\hline
\end{tabular}

1 Includes miscellaneous conifers such as ponderosa pine, pitch pine, Austrian pine, Douglas-fir, balsam fir, European larch, and a small acreage of unusual mixtures. Hardwood plantings are not included.

2 Excludes state forest plantings in Allegan County, for which records are not available. 


\section{Four-Fifths of the Plantings Successfully \\ Established}

By 1957, established forest plantations (by definition, having over 100 live planted trees per acre ) covered more than 4 out of every 100 acres of land or nearly 7 out of every 100 acres of commercial forest land in northern Lower Michigan. This reforested area is equal to one-fifth of the total pine acreage in the area, and is approximately equal to the total land in Grand Traverse and
Leelanau Counties combined (fig. 7 ). About 204,000 acres are on National Forest land, 158,000 acres on State Forest land, and 154,000 acres on private land.

Although about 660,600 acres were estimated to have been planted, only 517,000 acres were found to be established forest plantings. Of the difference, 81,700 acres were classed as failures on the State and National Forests, either because

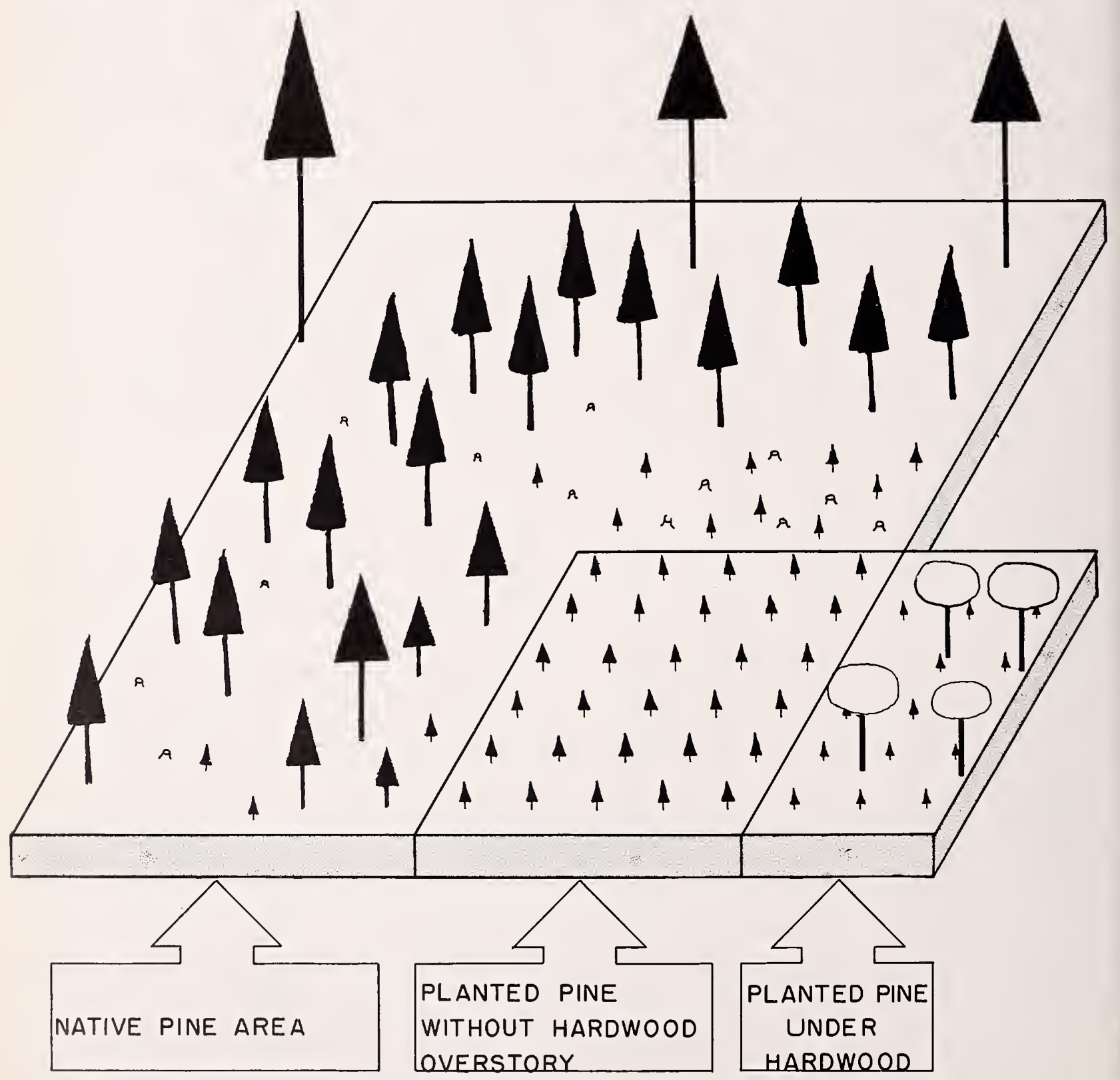

FIGURE 7. - Nearly one-fifth of the pine forest in northern Lower Michigan is plantation. 
the planted trees numbered less than the required minimum ( 100 per acre) or native reproduction was more numerous and promising than the planted trees. Also not included in established plantations are about 9,000 acres of trees in windbreaks or other small plantings of less than $2 \frac{1 / 2}{2}$ acres. The remainder is made up of the failures in private plantings, and any error in the acreage-planted estimate for private plantings arises from the assumption that an acre was planted for every 1,000 trees shipped. Less than 3 percent of the planted area has reverted to grass and brush.

of the half-million acres of established forest plantings, 454,500 are seedlings and saplings, 62,000 acres are poletimber, and 400 acres are sawtimber (table 4 ).

Medium and well-stocked plantations totaled 366,000 acres. Poor stocking was found on 116,000 acres of seedlings and saplings and 34,500 acres of poletimber. About 27,000 acres are classed as medium and well-stocked poletimber.

\section{Hardwood Competition Common}

About 200,000 acres ( 39 percent) of the established plantations have competing native tree overstories (native tree volumes of 3 or more cords per acre overtopping the plantation). Thirty-one

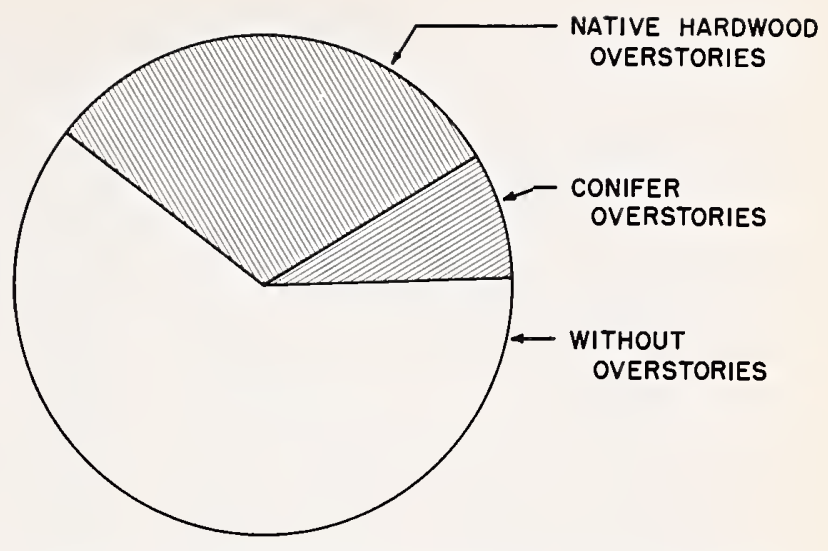

Figure 8. - Proportion of established plantations with conifer and hardwood overstories, northern Lower Michigan.

percent of the plantations are under hardwood overstories, 8 percent have conifer overstories (fig. 8 and table 5 ).

Sixty-two percent of the area of plantations in National Forests and 39 percent of those in State Forests were covered by overstories (fig. 9). Overstories were found in only 9 percent of the private plantings. Private plantings are still comparatively young and are generally on old fields. The hardwood trees in plantations tended to be more numerous in the older plantings.
Figure 9. - Established forest plantation acreages in northel'n Lower Michigan by owner and stand-size.

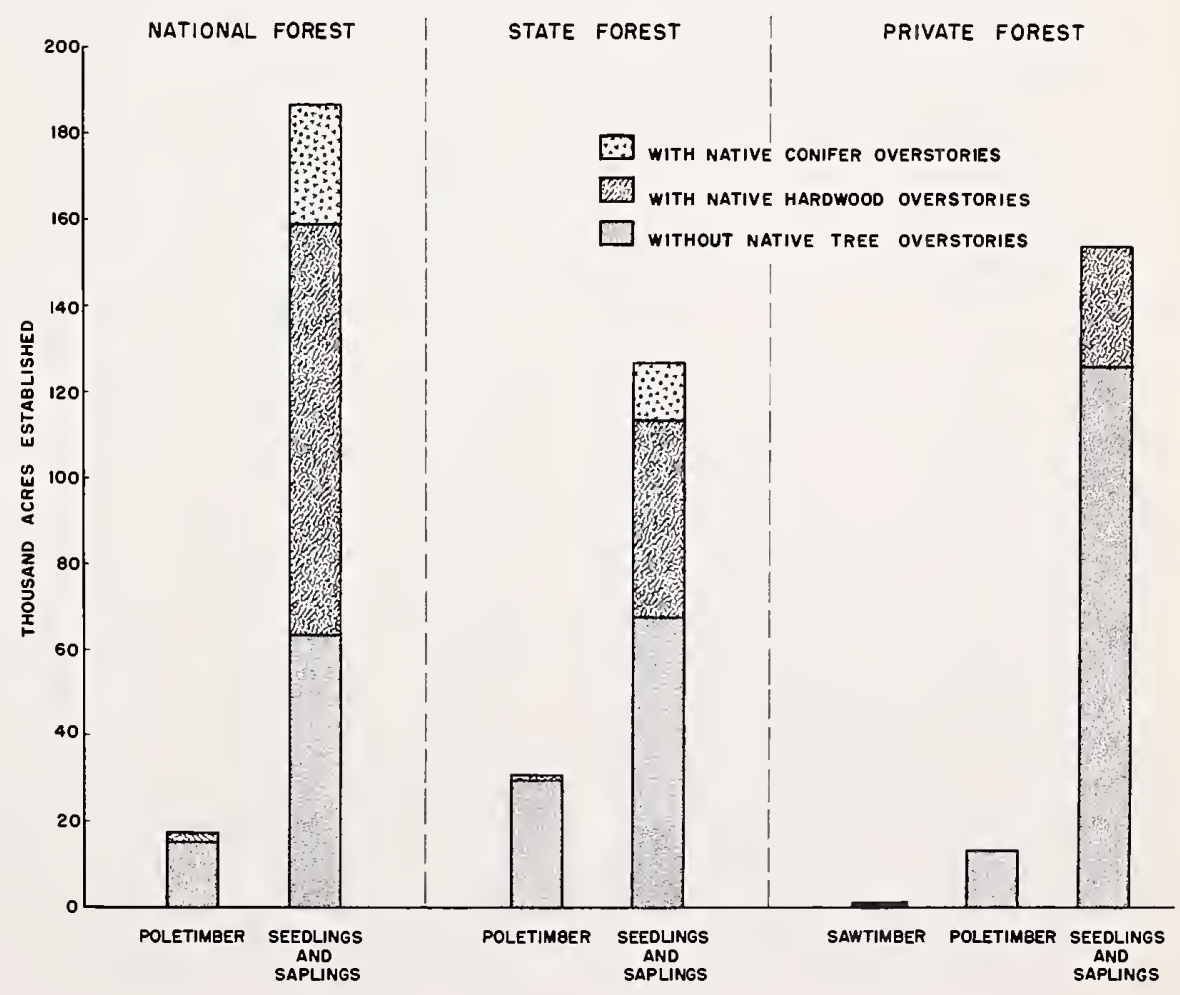


TABLE 4. - Established forest plantations in northern Lower Michigan by owner, type, sizc, and density class, 1957

(In acres)

\begin{tabular}{lrrrrr}
\hline \multirow{2}{*}{$\begin{array}{c}\text { Stand-size } \\
\text { and density } \\
\text { class }^{1}\end{array}$} & \multicolumn{5}{c}{ Plantation type } \\
\cline { 2 - 6 } & $\begin{array}{c}\text { All } \\
\text { types }\end{array}$ & $\begin{array}{c}\text { White } \\
\text { pine }\end{array}$ & $\begin{array}{c}\text { Red } \\
\text { pine }\end{array}$ & $\begin{array}{c}\text { Jack } \\
\text { pine }\end{array}$ & Spruce \\
\hline Seedlings and saplings : & & National Forest \\
Low & 42,400 & 6,900 & 33,600 & 1,700 & 200 \\
Medium & 58,300 & 2,900 & 46,200 & 8,700 & 500 \\
Good & 86,300 & 9,700 & 49,700 & 26,800 & 100 \\
Total & 187,000 & 19,500 & 129,500 & 37,200 & 800 \\
Poletimber: & 10,900 & - & 1,900 & 9,000 & - \\
Low & 5,500 & - & 2,800 & 2,700 & - \\
Medium & 1,000 & - & 700 & 300 & - \\
Good & 17,400 & - & 5,400 & 12,000 & - \\
Total & 204,400 & 19,500 & 134,900 & 49,200 & 800 \\
Total & & & & & \\
\hline
\end{tabular}

Seedlings and saplings:

Low

Medium

Good

Total

Poletimber:

\begin{tabular}{lrrrrr} 
Low & 16,000 & 400 & 1,900 & 13,300 & 400 \\
Medium & 10,800 & 600 & 1,700 & 8,500 & - \\
Good & 4,300 & 100 & 1,500 & 2,700 & - \\
\cline { 2 - 6 } Total & 31,100 & 1,100 & 5,100 & 24,500 & 400 \\
\cline { 2 - 6 } State Forest & 158,200 & 17,100 & 52,300 & 88,300 & 500 \\
\hline
\end{tabular}

Seedlings and saplings:

Low

Medium

Good

State Forest ${ }^{3}$

Total

\begin{tabular}{rrrrr}
56,100 & 11,500 & 22,600 & 22,000 & $(5)$ \\
40,200 & 2,900 & 14,100 & 23,200 & $(5)$ \\
30,800 & 1,600 & 10,500 & 18,600 & 100 \\
\hline 127,100 & 16,000 & 47,200 & 63,800 & 100 \\
\hline
\end{tabular}

timber:

Low

Medium

Good

Total

Sawtimber:

Medium

Total

Total Private

All Owners

\begin{tabular}{rrrrr}
17,900 & 8,300 & 5,700 & 2,800 & 1,100 \\
22,400 & 3,600 & 12,800 & 4,400 & 1,600 \\
100,100 & 7,400 & 59,100 & 30,800 & 2,800 \\
\hline 140,400 & 19,300 & 77,600 & 38,000 & 5,500 \\
\hline 7,600 & 1,400 & 2,600 & 3,600 & - \\
3,800 & 400 & 2,800 & 600 & - \\
2,100 & 400 & 1,500 & - & 200 \\
\hline 13,500 & 2,200 & 6,900 & 4,200 & 200 \\
\hline
\end{tabular}

Percent of area with

native tree overstories

\begin{tabular}{rrrrr}
400 & - & 400 & - & - \\
\hline 400 & - & 400 & - & - \\
\hline 154,300 & 21,500 & 84,900 & 42,200 & 5,700 \\
\hline 516,900 & 58,100 & 272,100 & 179,700 & 7,000 \\
\hline
\end{tabular}

$$
39.0
$$

64.2

43.5

26.7

13.1

1 Stand density class definitions: Low density, 3-6.9 cords or 100-400 seedlings per acre; Medium density, 7-12.9 cords or 400-700 secdlings pcr acre; Good density, 13+ cords or roo+ seedlings per acre.

Includes Scotch pine plantations.

Excludes State forest plantings in Allegan County.

Includes plantations on county and school forests and other small public holdings.

Le'ss than 50 acres. 
TABLE 5. - Established forest plantations in northern Lower Michigan by size class and county, 1957

(In acres)

\begin{tabular}{|c|c|c|c|c|c|c|c|}
\hline \multirow[b]{2}{*}{ County } & \multirow[b]{2}{*}{ Total } & \multicolumn{3}{|c|}{ Without native tree overstories } & \multicolumn{3}{|c|}{ With native tree overstories } \\
\hline & & Total & $\begin{array}{l}\text { Seedlings } \\
\text { and } \\
\text { saplings }\end{array}$ & $\begin{array}{l}\text { Pole- } \\
\text { timber }\end{array}$ & Total & $\begin{array}{l}\text { Seedlings } \\
\text { and } \\
\text { saplings }\end{array}$ & $\begin{array}{l}\text { Pole- } \\
\text { timber }\end{array}$ \\
\hline $\begin{array}{l}\text { Alcona } \\
\text { Allegan } \\
\text { Alpena } \\
\text { Antrim } \\
\text { Arenac }\end{array}$ & $\begin{array}{r}20,900 \\
5,400 \\
3,700 \\
7,500 \\
1,000\end{array}$ & $\begin{array}{r}11,900 \\
4,900 \\
1,900 \\
7,100 \\
1,000\end{array}$ & $\begin{array}{r}10,000 \\
4,400 \\
1,000 \\
6,600 \\
900\end{array}$ & $\begin{array}{r}1,900 \\
500 \\
900 \\
500 \\
100\end{array}$ & $\begin{array}{r}9,000 \\
500 \\
1,800 \\
400 \\
*\end{array}$ & $\begin{array}{r}8,700 \\
500 \\
1,700 \\
400 \\
*\end{array}$ & $\frac{300}{100}$ \\
\hline $\begin{array}{l}\text { Benzie } \\
\text { Charlevoix } \\
\text { Cheboygan } \\
\text { Clare } \\
\text { Crawford }\end{array}$ & $\begin{array}{r}8,800 \\
3,600 \\
19,800 \\
15,800 \\
21,300\end{array}$ & $\begin{array}{r}8,100 \\
2,400 \\
12,300 \\
10,800 \\
12,600\end{array}$ & $\begin{array}{l}7,400 \\
1,800 \\
8,800 \\
8,900 \\
8,500\end{array}$ & $\begin{array}{r}700 \\
600 \\
3,500 \\
1,900 \\
4,100\end{array}$ & $\begin{array}{r}700 \\
1,200 \\
7,500 \\
5,000 \\
8,700\end{array}$ & $\begin{array}{r}700 \\
1,200 \\
7,300 \\
4,900 \\
8,500\end{array}$ & $\begin{array}{l}- \\
200 \\
100 \\
200\end{array}$ \\
\hline $\begin{array}{l}\text { Emmet } \\
\text { Gladwin } \\
\text { Grand Traverse } \\
\text { Iosco } \\
\text { Kalkaska }\end{array}$ & $\begin{array}{r}4,400 \\
3,200 \\
\mathrm{e} 21,200 \\
47,100 \\
17,600\end{array}$ & $\begin{array}{r}3,800 \\
2,400 \\
14,700 \\
14,800 \\
12,200\end{array}$ & $\begin{array}{r}3,600 \\
1,700 \\
10,900 \\
10,600 \\
10,100\end{array}$ & $\begin{array}{r}200 \\
700 \\
3,800 \\
4,200 \\
2,100\end{array}$ & $\begin{array}{r}600 \\
800 \\
6,500 \\
32,300 \\
5,400\end{array}$ & $\begin{array}{r}600 \\
800 \\
6,400 \\
31,700 \\
5,200\end{array}$ & $\begin{array}{r}* \\
* \\
100 \\
600 \\
200\end{array}$ \\
\hline $\begin{array}{l}\text { Lake } \\
\text { Leelanau } \\
\text { Manistee } \\
\text { Mason } \\
\text { Mecosta }\end{array}$ & $\begin{array}{r}28,000 \\
4,100 \\
27,000 \\
14,900 \\
5,300\end{array}$ & $\begin{array}{r}11,300 \\
3,600 \\
14,700 \\
8,300 \\
4,000\end{array}$ & $\begin{array}{r}8,700 \\
3,400 \\
13,400 \\
7,300 \\
3,700\end{array}$ & $\begin{array}{r}2,600 \\
200 \\
1,300 \\
1,000 \\
300\end{array}$ & $\begin{array}{r}16,700 \\
500 \\
12,300 \\
6,600 \\
1,300\end{array}$ & $\begin{array}{r}16,300 \\
500 \\
12,200 \\
6,500 \\
1,300\end{array}$ & $\begin{array}{l}400 \\
100 \\
100 \\
*\end{array}$ \\
\hline $\begin{array}{l}\text { Midland } \\
\text { Missaukee } \\
\text { Montmorency } \\
\text { Muskegon } \\
\text { Newaygo }\end{array}$ & $\begin{array}{r}2,900 \\
10,500 \\
15,700 \\
13,900 \\
33,900\end{array}$ & $\begin{array}{r}2,700 \\
9,600 \\
10,300 \\
12,400 \\
17,300\end{array}$ & $\begin{array}{r}1,700 \\
9,300 \\
7,600 \\
10,500 \\
15,000\end{array}$ & $\begin{array}{r}1,000 \\
300 \\
2,700 \\
1,900 \\
2,300\end{array}$ & $\begin{array}{r}200 \\
900 \\
5,400 \\
1,500 \\
16,600\end{array}$ & $\begin{array}{r}200 \\
900 \\
5,300 \\
1,500 \\
16,300\end{array}$ & $\begin{array}{r}- \\
100 \\
* \\
300\end{array}$ \\
\hline $\begin{array}{l}\text { Oceana } \\
\text { Ogemaw } \\
\text { Osceola } \\
\text { Oscoda } \\
\text { Otsego }\end{array}$ & $\begin{array}{r}8,600 \\
8,000 \\
6,400 \\
35,700 \\
15,800\end{array}$ & $\begin{array}{r}6,000 \\
4,800 \\
6,100 \\
14,800 \\
11,200\end{array}$ & $\begin{array}{r}5,600 \\
2,800 \\
5,800 \\
12,300 \\
9,100\end{array}$ & $\begin{array}{r}400 \\
2,000 \\
300 \\
2,500 \\
2,100\end{array}$ & $\begin{array}{r}2,600 \\
3,200 \\
300 \\
20,900 \\
4,600\end{array}$ & $\begin{array}{r}2,600 \\
3,100 \\
300 \\
20,600 \\
4,500\end{array}$ & $\begin{array}{r}* \\
100 \\
300 \\
100\end{array}$ \\
\hline $\begin{array}{l}\text { Ottawa } \\
\text { Presque Isle } \\
\text { Roscommon } \\
\text { Wexford }\end{array}$ & $\begin{array}{l}19,100 \\
12,900 \\
14,300 \\
38,600\end{array}$ & $\begin{array}{r}17,500 \\
7,900 \\
7,300 \\
24,600\end{array}$ & $\begin{array}{r}15,500 \\
5,100 \\
2,800 \\
22,200\end{array}$ & $\begin{array}{l}2,000 \\
2,800 \\
4,500 \\
2,400\end{array}$ & $\begin{array}{r}1,600 \\
5,000 \\
7,000 \\
14,000\end{array}$ & $\begin{array}{r}1,600 \\
4,800 \\
6,700 \\
13,700 \\
\end{array}$ & $\begin{array}{l}2 \overline{-} \\
300 \\
300 \\
\end{array}$ \\
\hline Total & 516,900 & 315,300 & 257,000 & 58,300 & 201,600 & 197,500 & 4,100 \\
\hline
\end{tabular}

* Less than 50 acres. 


\section{PLANTATION DEVELOPMENT}

A general picture of the way forest plantations have developed in northern Lower Michigan was gained by analyzing the number of trees, height, basal area, and volume at different ages in stands without native overstories. It must be stressed that these results are from an extensive survey and not from controlled experiments.

\section{Number of Trees}

In plantations as in natural stands the number of living trees has declined as age increased (fig. 10 ). During the first 35 years after planting, the number of live trees in average plantations declined 62 percent in white pine plantings, 59 percent in jack pine, and 46 percent in red pine. The reduction in planted trees is described by regression equations on figure 10.

\section{Height Growth}

The average planted tree without overstory competition is growing about 10 inches taller each year. Jack pine on the average has increased its height slightly faster than red pine and white pine (fig. 11). This pattern will probably reverse as

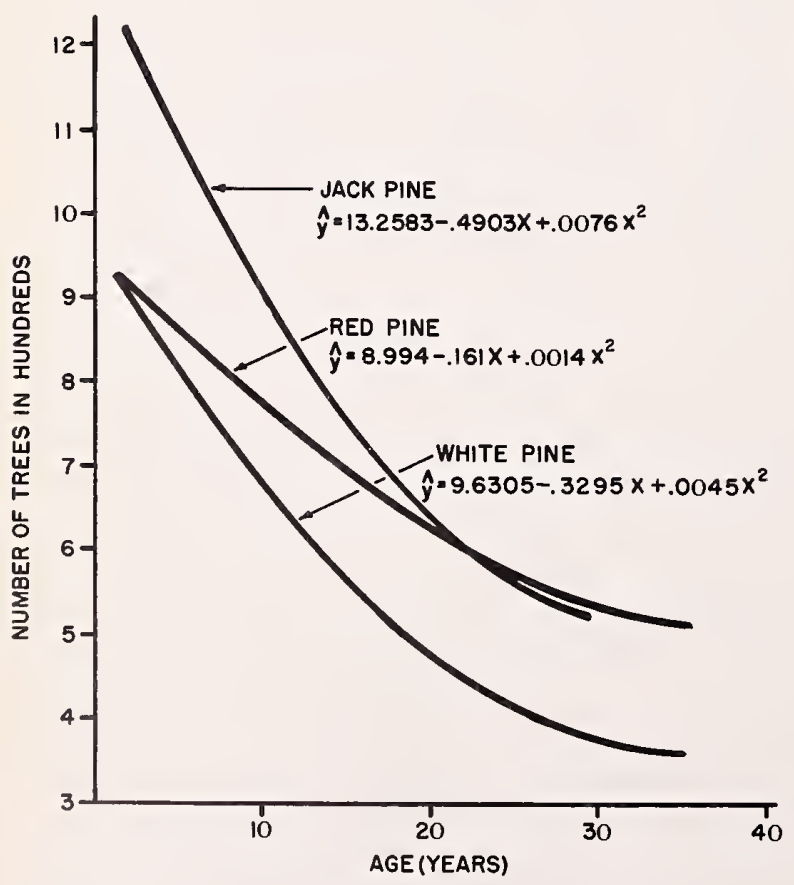

FIGURE 10. - Relationship between numbers of planted trees per acre and age, northern Lower Michigan.

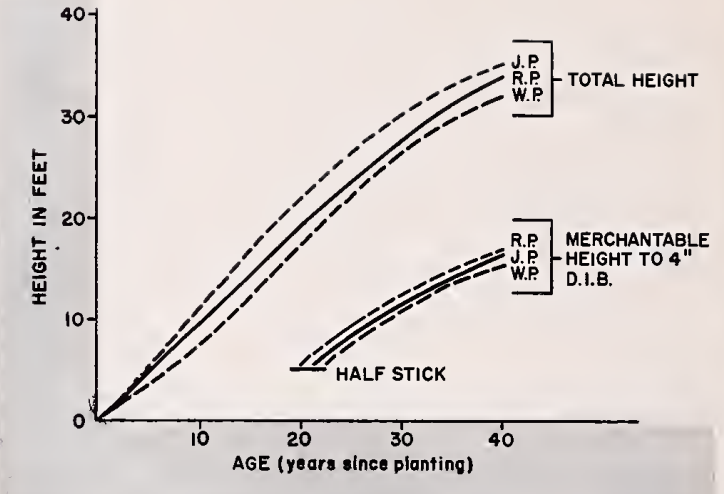

FIgURE 11. - Relationships between the total height and merchantable length of red pine, white pine, and jack pine, northern Lower Michigan plantations.

the plantations mature since jack pine is a shorter lived species than either red or white pine. Jack pine between 30 and 40 years grows in height at a slower rate than in younger stands. White pine heights reflect damage by the white-pine weevil.

Merchantable length (height to 4.0 inches diameter inside bark ) had about the same relationship among species as did total height; it was greatest in jack pine, medium in red pine, and shortest in white pine. However, red pine between 30 and 40 years of age overtook and passed jack pine in merchantable length (fig. 12 ).

Competition of native overstories retards plantation development. The typical height growth with overstories is illustrated by red pine in figure 13 . Heights of jack pine and white pine where overstories are present were also only about half the height of stands that had no tree competition.

\section{Diameter Growth}

The pattern of height growth among species compared closely to that of diameter growth, with jack pine leading red and white pine throughout the first two decades after planting. Red and white pine diameters overtook and exceeded the diameters of jack pine at about 30 years of age (fig. 14 ).

Average stand diameter for plantations without native overstories was 5 inches at about 30 years for all three species. 
Figure 12. - Average total height and merchantable le $\mathrm{ngth}$ for planted white, red, and jack pine with and without native $t r e e$ overstories, northern Lower Michigan.

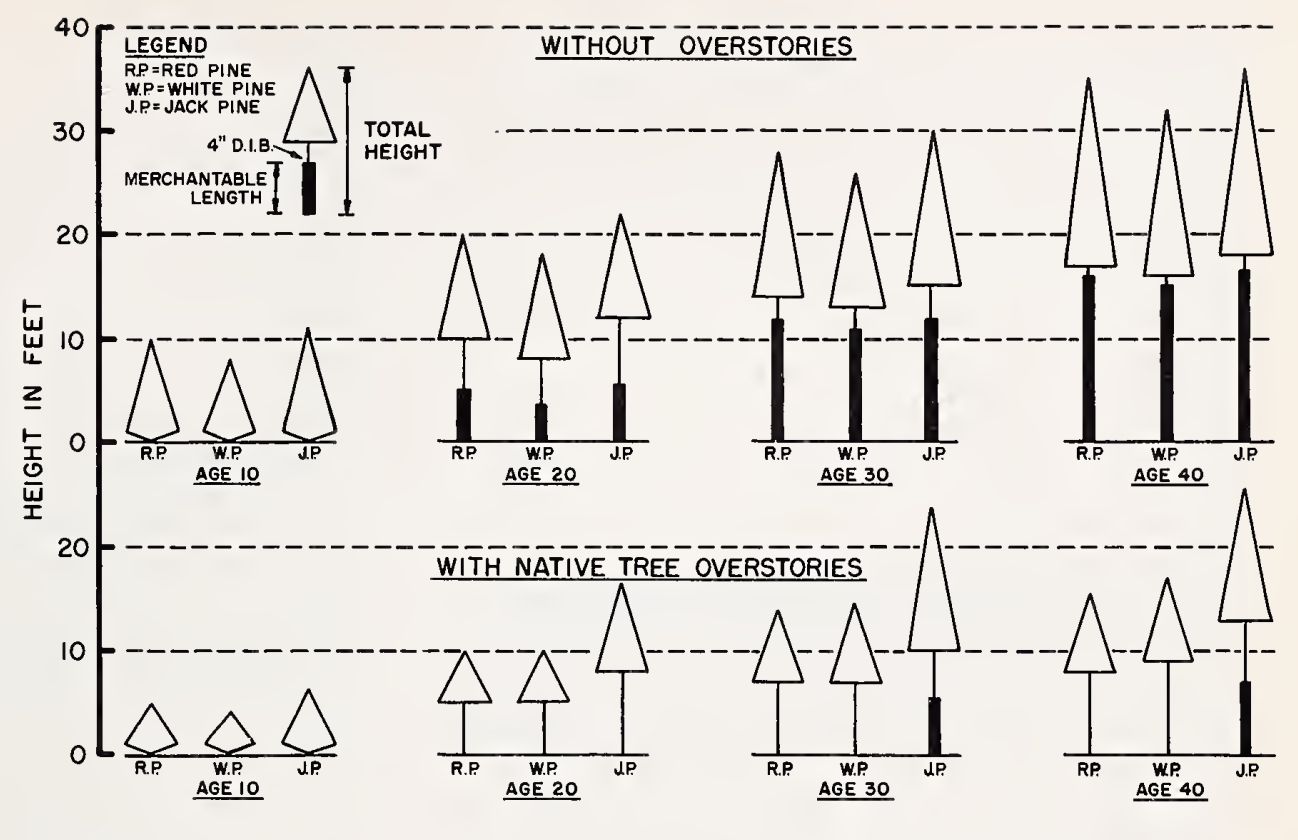

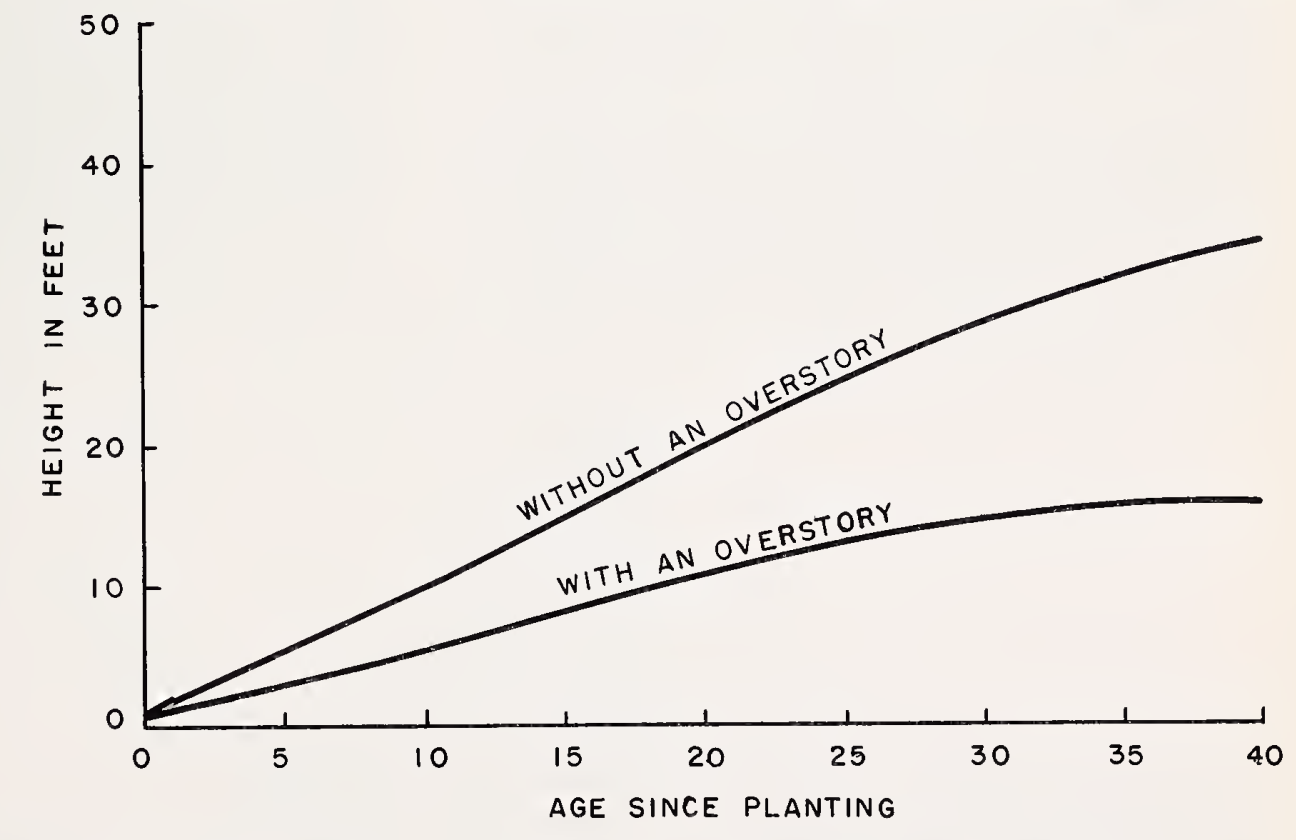

Figure 13. - Height growth of planted red pine with and without overstories, northern Lower Michigan.
Red pine diameter was about half as great in plantings with native overstories as in those without them (fig. 15). Overstory competition apparently affected jack and white pine diameter growth in the same manner.

\section{Basal Area}

Average basal area increased at a fairly constant rate in plantations up to age 40 (fig. 16). Red pine plantings had the highest average basal area per acre until around 20 years of age; thereafter the average for white pine was higher. Jack pine had the lowest average basal area of the three species. The mean annual increase of basal area was 3.0 square feet for white pine, 2.2 for red pine, and 2.0 for jack pine through 40 year of age. These growth rates are less than half those being achieved under management on experimental plots. The Higgins Lake, Mich., Bosom Field red pine plantings showed 5.0 square feet of growth per year. ${ }^{3}$ Part of the poor showing of the plantations

3 Unpublished progress report, Lake States Forest Experiment Station. 


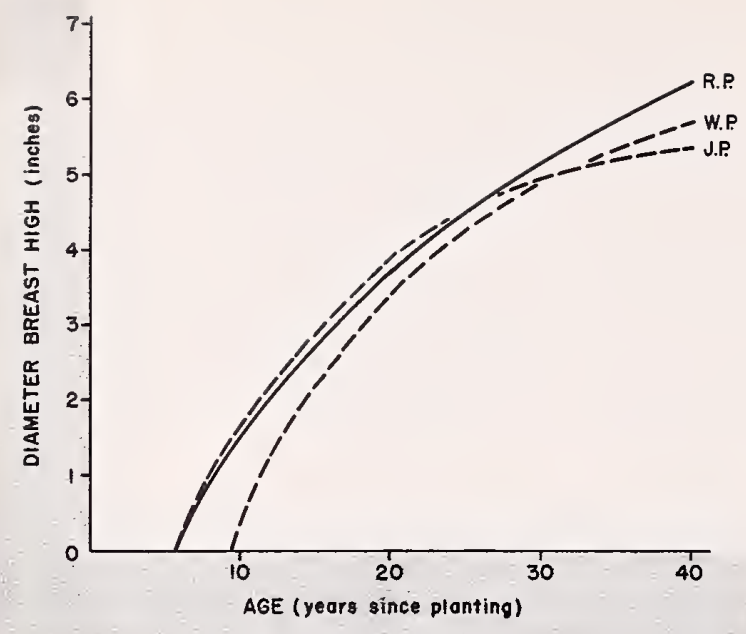

Figure 14. - Relationship between average diameter and age of red, white, and jack pine in plantings without native tree overstories, northern Lower Michigan.

can be explained by the low stocking levels of many of them.

\section{Volume}

Measurable volume in plantation trees 5 inches or larger d.b.h. occurred about the 15 th year and during the next 10 to 15 years increased rapidly. Differences in volume per acre between planted

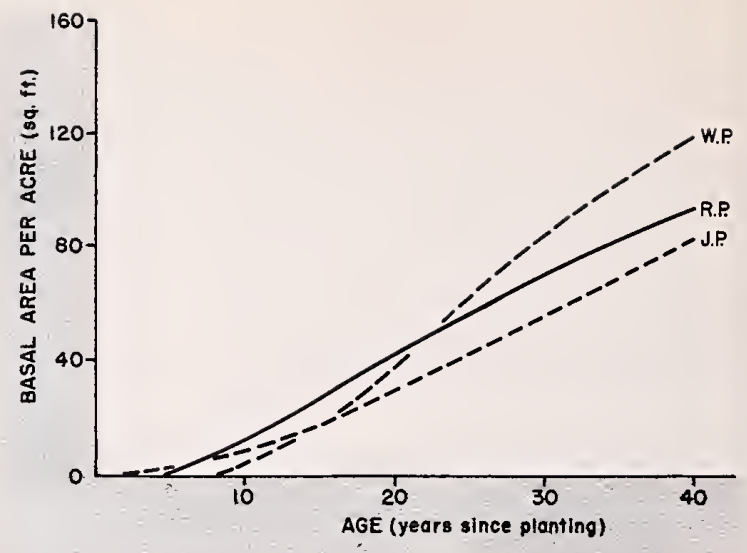

Figure 16. - Relationship between basal area per acre and age for planted white, red, and jack pine without native tree overstories, northern Lower Michigan.

species were small through the first 20 years after planting, with red pine and white pine having slightly larger average volumes than jack pine (fig. 17). After age 30 red pine continued adding volume at its previous pace, but white pine and jack pine growth rates declined. However, only a small number of plantations over 30 years were available for measurement.

The apparent effect of native overstories shows more strikingly in comparisons of volume than in
Figure 15. - Diameter growth of planted red pine with and without overstories, northern Lower Michigan.

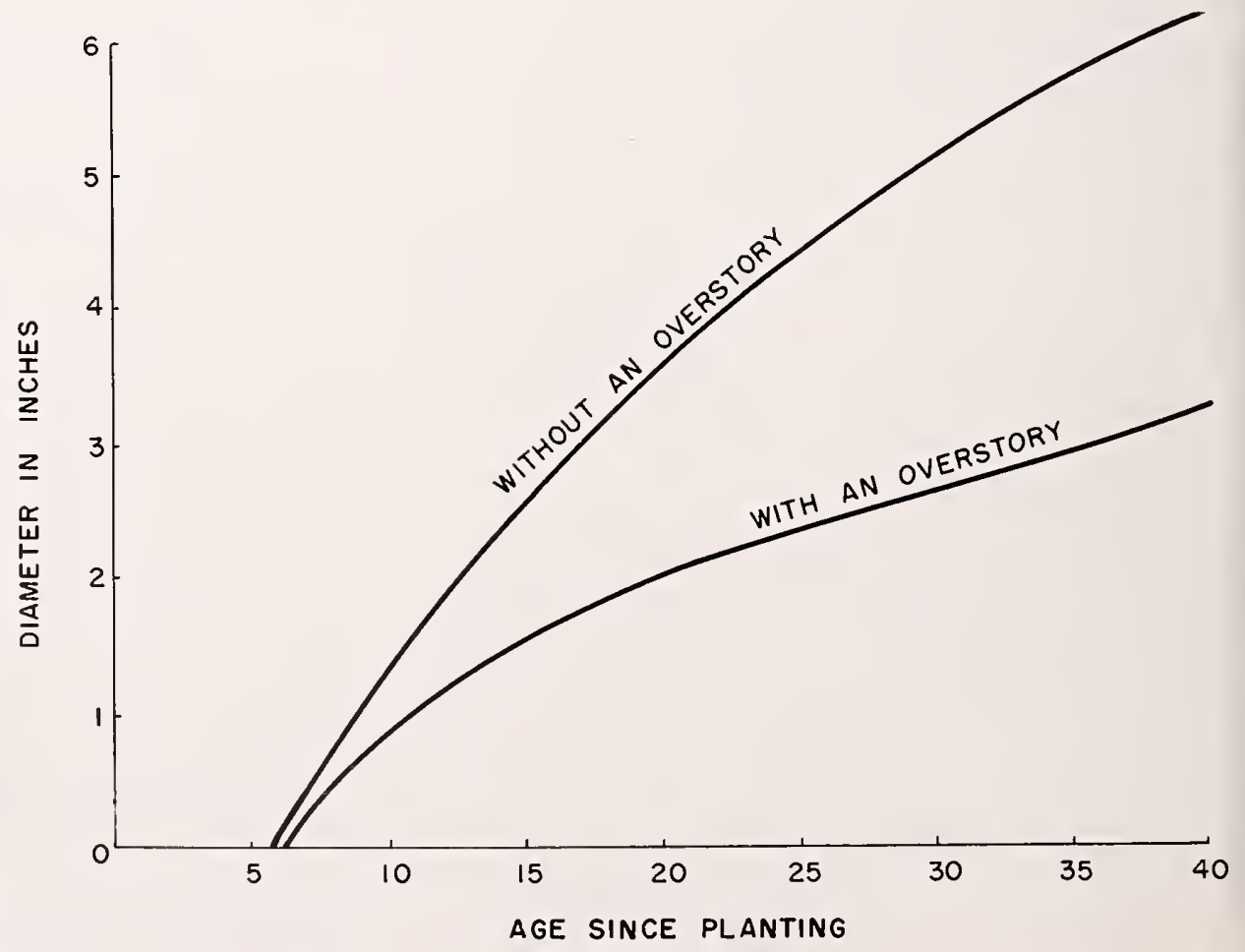




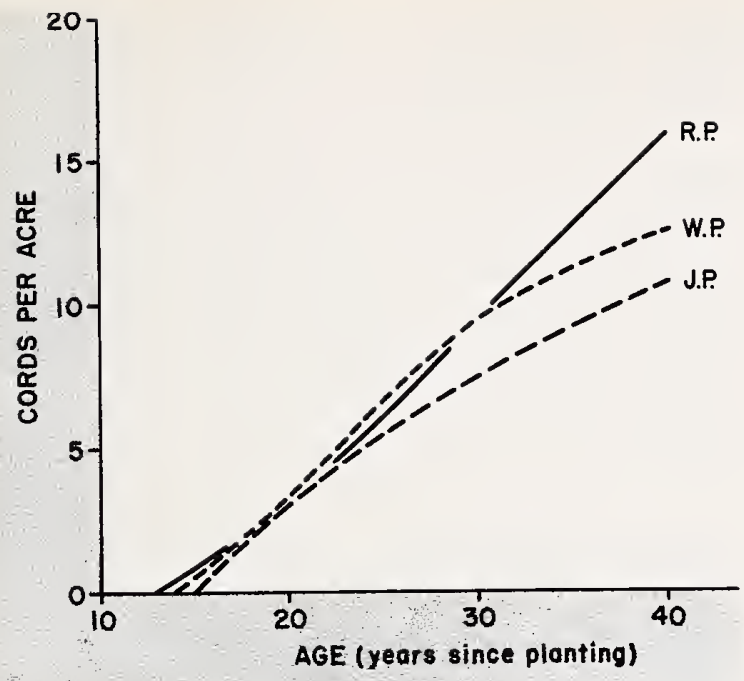

Figure 17. - Relationship between volume per acre and age of planted white, red, and jack pine in northern Lower Michigan.

either height or diameter growth. With the majority of the plantations less than 30 years of age, those delayed by overstories have few trees over 5 inches d.b.h. and, thus, little measurable volume (fig. 18 ).

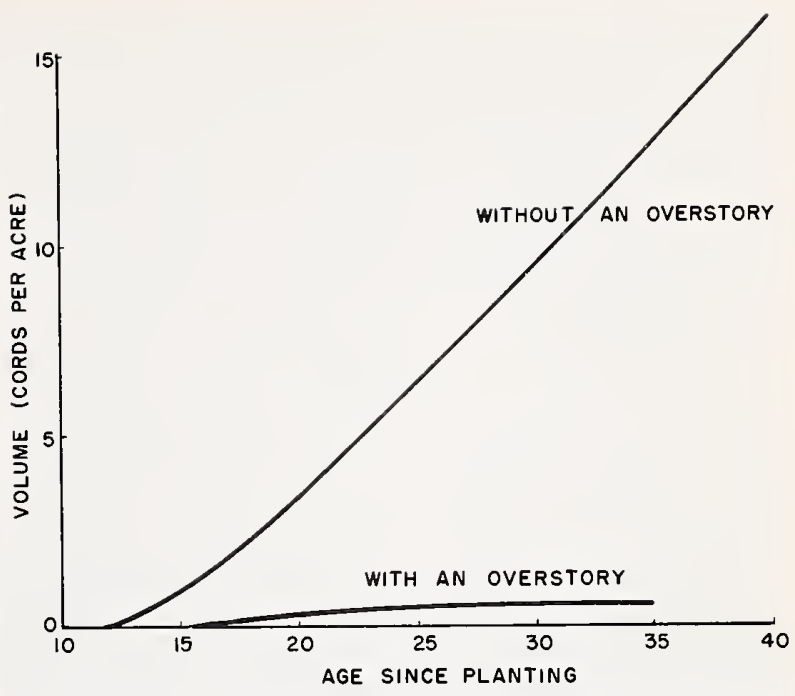

Figure 18. - Volume of red pine in plantations without a native overstory and with a native overstory of 3 cords or more per acre.

The ultimate development of plantations in northern Lower Michigan cannot be reliably estimated until plantings reach maturity on various sites, although many are doing well. Presently, the oldest plantings are about 50 years old and are far from their potential development.
Figure 19. - Relationship between size class and age of plantations without and with overstories, nopthern Lower Michigan.

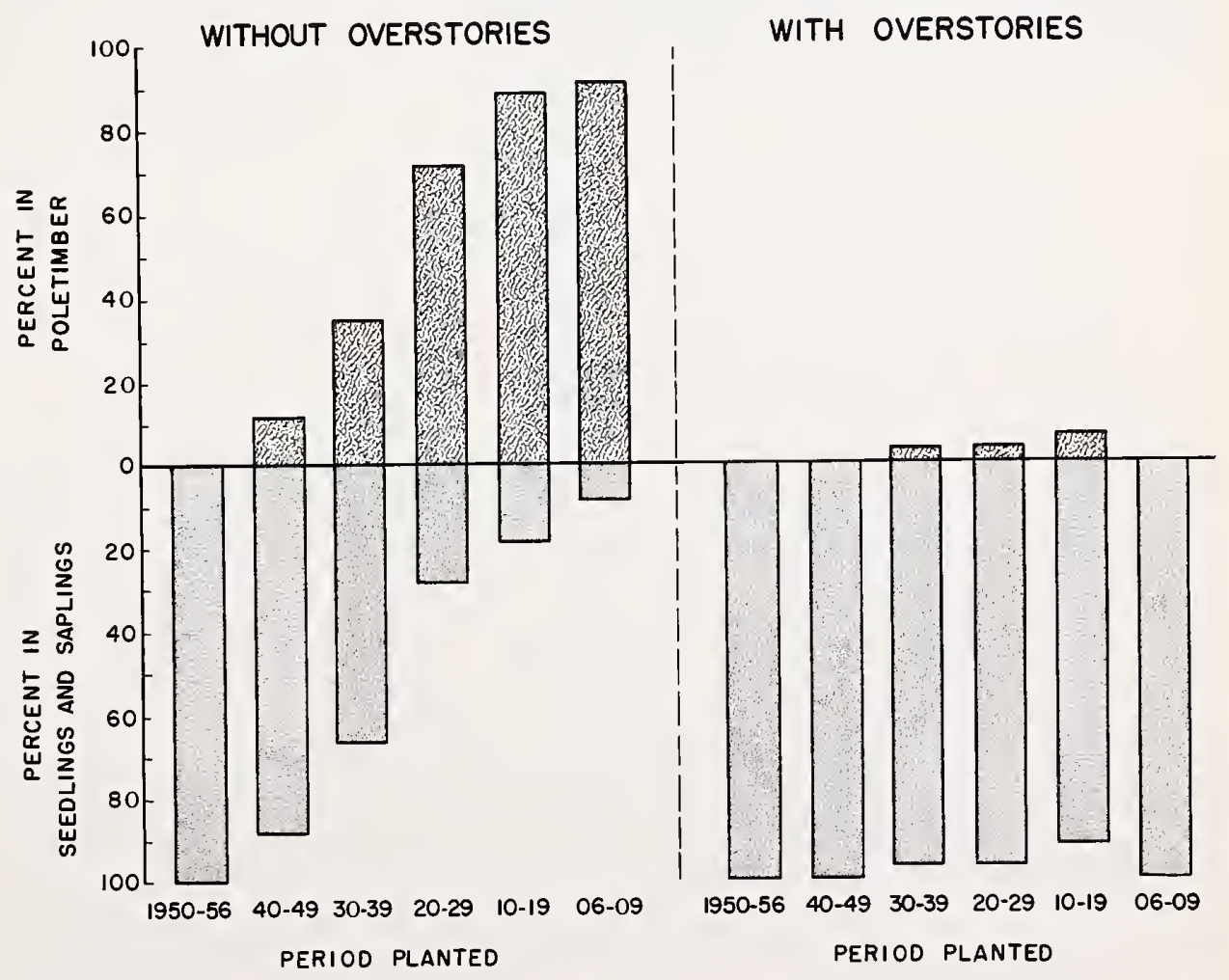




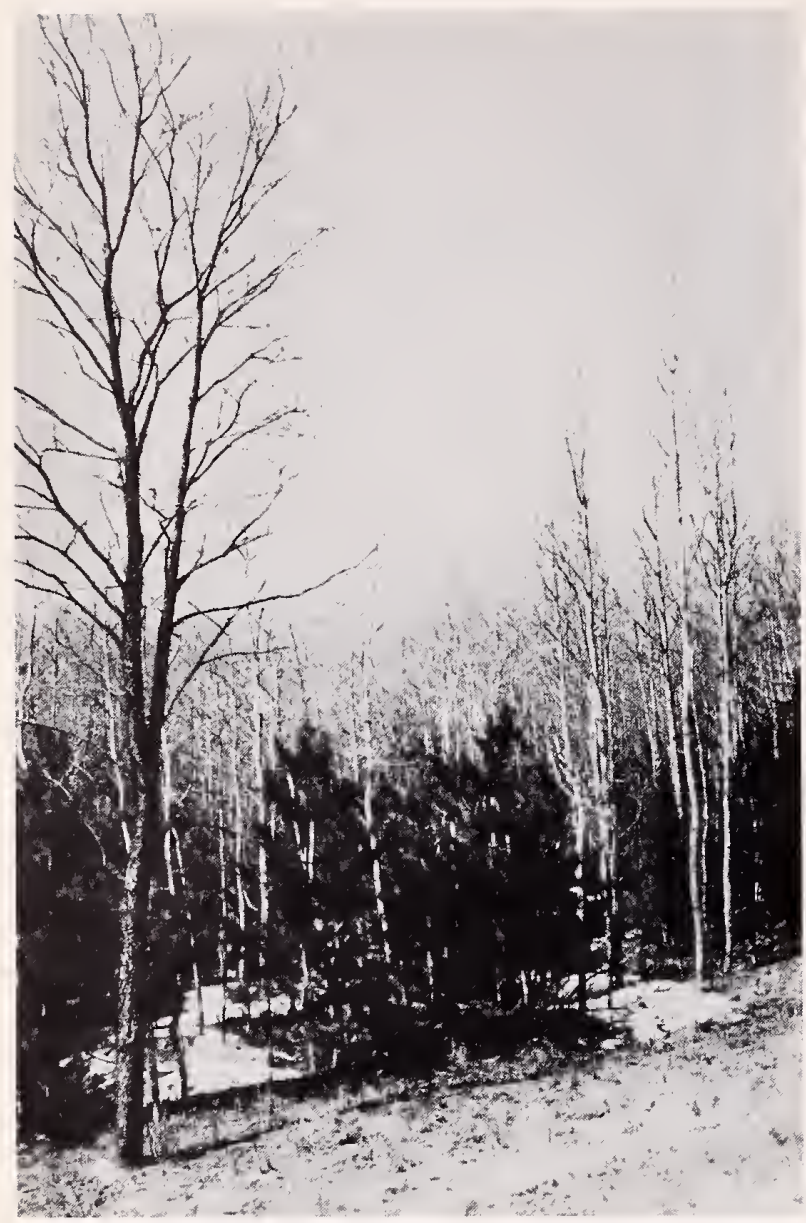

At 30 years over half of the plantations without native overstories have reached poletimber size and by 50 years 90 percent are poletimber or larger (fig. 19). On the other hand, less than 3 percent of the plantations with overstories are of poletimber size in 30 years. Competition from native trees appears to be the key factor delaying plantation development (fig. 20). Other factors, of course, are more important in certain localities and particular plantations.

\section{F-500776}

Figure 20. Native tree overstories are slowing plantation development on over 200,000 acres in northern Lower Michigan. These 20year old red pine are less than half as tall as average ones without overstories. 


\section{- volume, growth, and allowable cut}

\section{Volume and Growth Increasing Rapidly}

Volume in the forest plantations of northern Lower Michigan totaled about 585,000 cords in 1957 (table 6 ). This volume includes all planted trees over 5 inches d.b.h. to a merchantable top of 4 inches d.i.b. The volume in plantations without native tree overstories was 526,000 cords, and those with overstories contained the remaining 59,000 cords. Although only 61 percent of the plantation area has no native overstories, this class contains 90 percent of the plantation volume.

The jack and red pine plantings include nearly 90 percent of the volume in stands both with and without native overstories.

Even though the older plantings have higher volumes per acre, the greatest volume in any 10year age group is in the $1930-39$ plantations (table 7 ). Trees planted during this decade cover 42 percent of the area and contain 53 percent of the total volume.

Plantations on State Forests have 44 percent of the volume (over 250,000 cords), National Forest plantings include 32 percent, and private plantations 24 percent of the volume.

Nine-tenths of the plantings have been established since 1930, and most are still seedlings and saplings with little measurable volume. Average merchantable length increases rapidly in younger stands, with the average doubling between 20 and 30 years of age. Volume should triple during the next decade. It could climb even higher if suppressed plantings are released on the 200,000 acres with native overstories.

As the many young plantations grow to poletimber size, net growth will increase. If these plantations continue to grow as the older ones have, poletimber acreage will be 136,000 acres by 1967 - more than doubling the 1957 acreage in this size-class. For the 10-year period 1957-66, net growth on planted trees is estimated at 941,800 cords (tables 8 and 9 ).

By 1967 the red pine plantations should have greater volume than the jack pine plantings as total volume triples. During 1957-66 over half ( 54 percent) of all plantation growth will be red pine.

At the end of this period private plantations should have the greatest volume, followed by Stateowned, and then by National Forest plantations.

Only 6 percent of the net growth during the next 10 years will be in plantations with native overstories, although they cover 39 percent of the planted acreage.

TABLE 6. - Net timber volume in forest plantations of northern Lower Michigan by forest type and ouner group, 1957

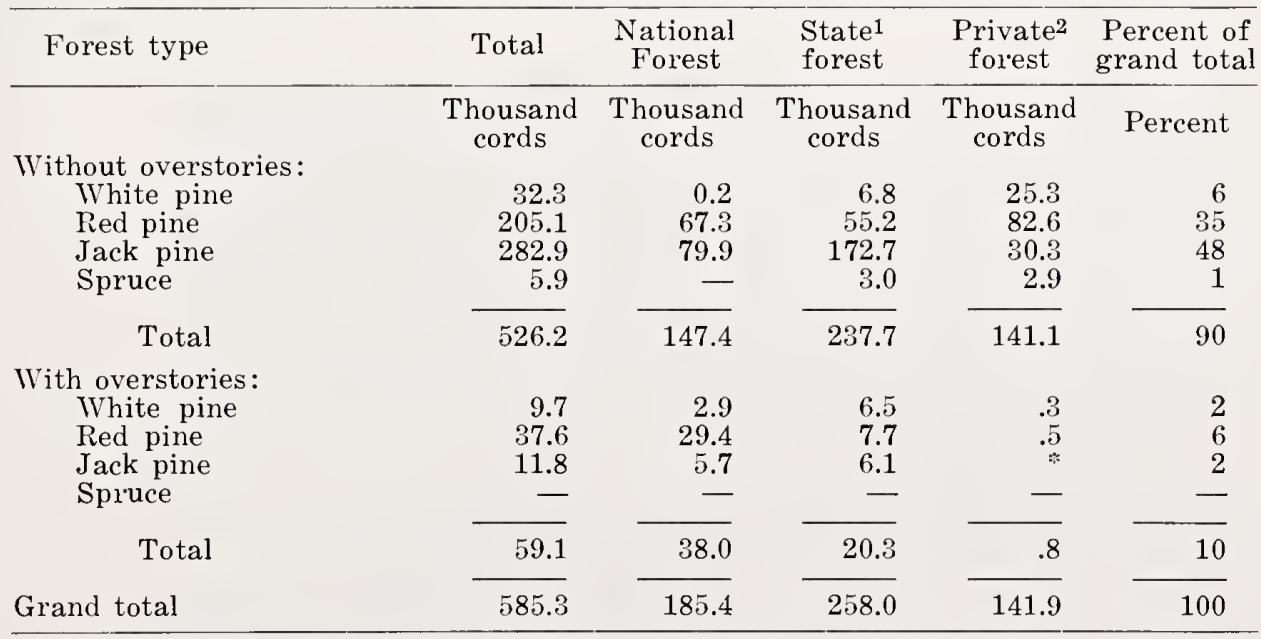

1 Excludes State forest plantings in Allegan County.

2 Includes plantations on county and school forests and other small public holdings. Less than 500 cords. 
TABLE 7. - Net timber volume in forest plantations of northern Lower Michigan, by decade planted and owner, 1957

\begin{tabular}{|c|c|c|c|c|c|}
\hline Decade planted & Total & $\begin{array}{c}\text { National } \\
\text { Forest }\end{array}$ & $\begin{array}{l}\text { Statel } \\
\text { forest }\end{array}$ & $\begin{array}{l}\text { Private }{ }^{2} \\
\text { forest }\end{array}$ & $\begin{array}{l}\text { Percent of } \\
\text { grand total }\end{array}$ \\
\hline & $\begin{array}{l}\text { Thousand } \\
\text { cords }\end{array}$ & $\begin{array}{l}\text { Thousand } \\
\text { cords }\end{array}$ & $\begin{array}{l}\text { Thousand } \\
\text { cords }\end{array}$ & $\begin{array}{l}\text { Thousand } \\
\text { cords }\end{array}$ & Percent \\
\hline $\begin{array}{l}\text { Without overstories: } \\
1900-09\end{array}$ & 0.6 & - & 0.6 & - & * \\
\hline $1910-19$ & 52.3 & 4.7 & 42.6 & 5.0 & 9 \\
\hline $1920-29$ & 161.2 & 18.1 & 103.1 & 40.0 & 27 \\
\hline $1930-39$ & 267.0 & 112.1 & 88.2 & 66.7 & 46 \\
\hline $1940-49$ & 45.1 & 12.5 & 3.2 & 29.4 & 8 \\
\hline $1950-56$ & - & - & - & - & 一 \\
\hline Total & 526.2 & 147.4 & 237.7 & 141.1 & 90 \\
\hline $\begin{array}{c}\text { With overstories: } \\
1900-09\end{array}$ & - & 一 & - & - & - \\
\hline $1910-19$ & 2.6 & .1 & $\overline{2.5}$ & 二 & $\bar{*}$ \\
\hline $1920-29$ & 16.7 & 4.9 & 11.7 & .1 & 3 \\
\hline $1930-39$ & 38.9 & 32.1 & 6.1 & .7 & 7 \\
\hline $1940-49$ & .9 & .9 & - & - & * \\
\hline $1950-56$ & - & 一 & 一 & 一 & - \\
\hline Total & 59.1 & 38.0 & 20.3 & .8 & 10 \\
\hline Grand total & 585.3 & 185.4 & 258.0 & 141.9 & 100 \\
\hline
\end{tabular}

Percent

1 Excludes State forest plantings in Allegan County.

2 Pncludes plantings on county and school forests and other small public holdings.

* Less than 0.5 percent.

TABLE 8. - Estimated periodic net growth in the forest plantations of northern Lower Michigan by forest type and owner, 1957-1966

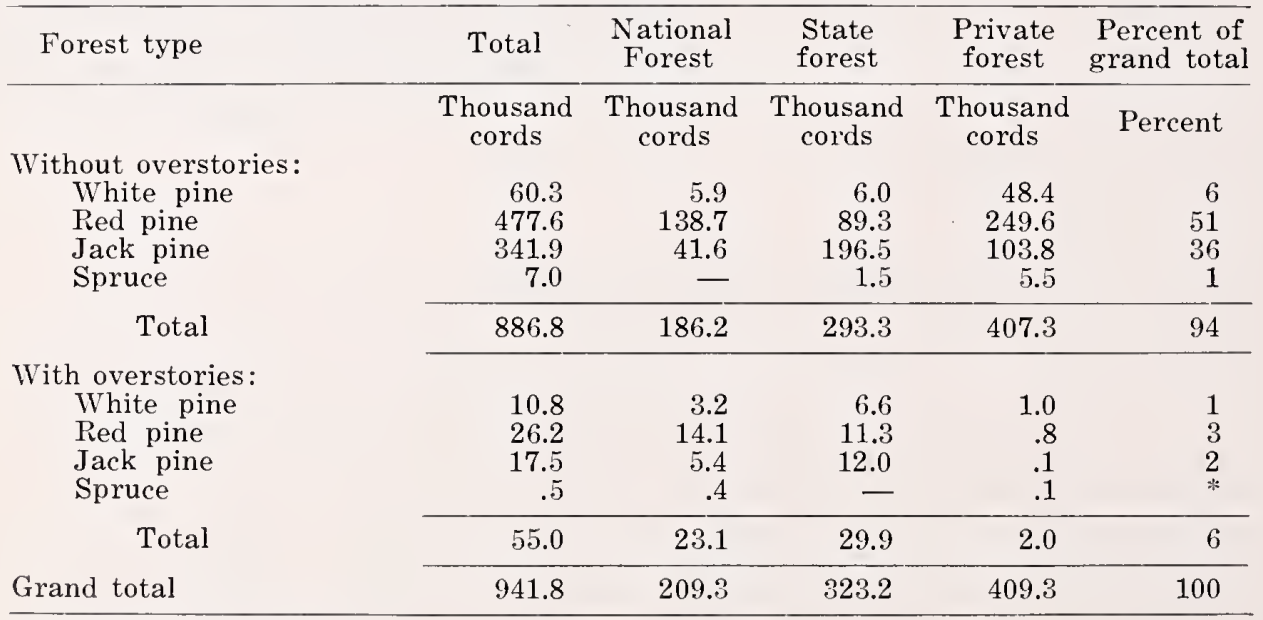

* Less than 0.5 percent.

\section{Allowable Cut Is 150,000 Cords}

With half a million cords of plantation wood present now and growth of about 940,000 cords expected in the next 10 years, the annual allowable cut is estimated as follows (the method of computing allowable cut is presented in the appendix ):
Forest type

White pine

Red pine

Jack pine ${ }^{1}$

Spruce

Total

1 Includes Scotch pine.
Cords per year

1400

9,300

4,100

500

15,300 
TABLE 9. - Estimated periodic net growth in the forest plantations of northern Lower Michigan by decade planted and owner, 1957-1966

\begin{tabular}{|c|c|c|c|c|c|}
\hline Decade planted & Total & $\begin{array}{c}\text { National } \\
\text { Forest }\end{array}$ & $\begin{array}{l}\text { State } \\
\text { forest }\end{array}$ & $\begin{array}{l}\text { Private } \\
\text { forest }\end{array}$ & $\begin{array}{l}\text { Percent of } \\
\text { grand total }\end{array}$ \\
\hline & $\begin{array}{l}\text { Thousand } \\
\text { cords }\end{array}$ & $\begin{array}{l}\text { Thousand } \\
\text { cords }\end{array}$ & $\begin{array}{l}\text { Thousand } \\
\text { cords }\end{array}$ & $\begin{array}{l}\text { Thousand } \\
\text { cords }\end{array}$ & Percent \\
\hline $\begin{array}{c}\text { Without overstories: } \\
1900-09\end{array}$ & 01 & $*$ & 01 & - & $* *$ \\
\hline $\begin{array}{l}1900-09 \\
1910-19\end{array}$ & $\begin{array}{l}0.1 \\
9.7\end{array}$ & 0.8 & 8.9 & * & 1 \\
\hline $1920-29$ & 98.3 & 1.4 & 92.7 & 4.2 & 10 \\
\hline $1930-39$ & 395.2 & 105.8 & 169.3 & 120.1 & 42 \\
\hline $1940-49$ & 225.0 & 38.1 & 14.3 & 172.6 & 24 \\
\hline $1950-56$ & 158.5 & 40.1 & 8.0 & 110.4 & 17 \\
\hline Total & 886.8 & 186.2 & 293.3 & 407.3 & 94 \\
\hline $\begin{array}{l}\text { With overstories: } \\
1900-09\end{array}$ & - & - & - & - & - \\
\hline $\begin{array}{l}1900-09 \\
1910-19\end{array}$ & $\overline{1.3}$ & $\overline{.2}$ & $\overrightarrow{1.1}$ & - & $\overline{* *}$ \\
\hline $1920-29$ & 9.6 & .9 & 8.4 & .3 & 1 \\
\hline $1930-39$ & 31.9 & 11.8 & 19.5 & .6 & 3 \\
\hline $1940-49$ & 12.2 & 10.2 & .9 & 1.1 & 2 \\
\hline $1950-56$ & & & 一 & - & - \\
\hline Total & 55.0 & 23.1 & 29.9 & 2.0 & 6 \\
\hline Grand total & 941.8 & 209.3 & 323.2 & 409.3 & 100 \\
\hline
\end{tabular}

* Less than 500 cords.

* Less than 0.5 percent.

About 15,000 cords can be thinned each year from forest plantations in northern Lower Michigan during the next decade (fig. 21). Sixty percent of this should be from red pine plantations, 27 percent from jack pine, 9 percent from white pine, and 4 percent from spruce.

The annual allowable cut of 15,000 cords equals only 17 percent of the net periodic growth. Presently most of the growth is in stands with too little volume to warrant a commercial thinning. Allowable cut in plantations will increase sharply as total growth and volume expand. A larger proportion of the growth can then be removed since more of the plantations will support commercial thinnings.

One problem in profitably harvesting the present allowable cut is that much of the volume is still in "one-stick" trees where the cost of felling each tree must be charged to a single bolt. Associated with this problem is the lack of markets for half sticks. As more of the trees reach 2-stick merchantable length, problems in profitably thinning plantations will diminish.

Most of the allowable cut for the next 10 years will come from public plantings, since over threequarters of the present plantation poletimber is found in National and State Forests.
F-494009

Figure 21. - About 150,000 cords can be thinned from plantations in northern L o w e $r$ Michigan in the next 10 years.

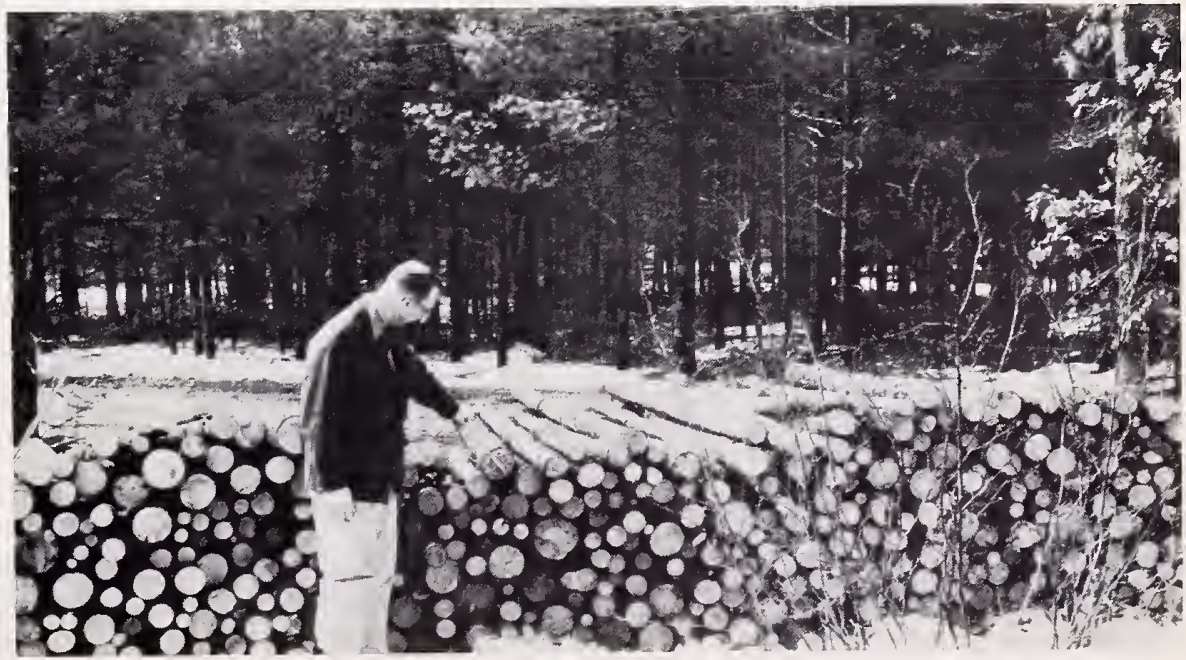




\section{DAMAGE IN PLANTATIONS}

Plantations, since they are even-aged and usually of only one species, are threatened with a higher rate of insect and disease injury than most native stands. As the plantings mature, however, the threat of damage tends to decline toward that of native forest cover. Observations to detect damage were made on all sample plots. The procedure was to indicate those sample plots on which the number of trees, basal area, or cord volume has been affected by disease, insects, or other factors. Injury was classed as serious damage if one-third of the trees on a plot had been killed or their wood production reduced.

Nearly one-fifth of the established plantation area $(102,000$ acres $)$ has been seriously damaged. Thirteen percent of the area of plantations with overstories showed damage, compared with 24 percent of the area of plantations without overstories. Reduced damage in plantations having overstories was associated with much lower rates of injury from white-pine weevil and European pine shoot moth.

Of the planted species, red pine was damaged the least. Except for Scotch pine, the single-species plantings had less severe damage than the mixtures (table 10). ${ }^{4}$ Ironically, the mixtures were planted to reduce the risk of damage. Determining the reasons for the greater damage in mixed plantations was beyond the scope of this study, although two factors that may be associated with it were noted. Mixed plantations occurred on poorer sites than plantings of a single species, and much

4 Rudolf, 1950. See footnote 2, page 1. of the damage was caused by insects such as whitepine weevil, jack-pine budworm, and European pine shoot moth, which attack several species of pine.

In the plantations without native overstories 90 percent of the damage was caused by insects (table 10 ), 53 percent by the white-pine weevil, 29 percent by the European pine shoot moth, and the remainder by various other insects (fig. 22). In plantations with native overstories 63 percent of the damage was by insects, usually the white-pine weevil. Other insects observed damaging plantations include the root collar weevil, pine tortoise scale, jack-pine budworm, and the redheaded pine sawfly. Damage was recorded separately only for the white-pine weevil and European pine shoot moth; the fieldmen were not sufficiently familiar with other insects and their damage characteristics to assign injury to individual species.

The 10 percent of damage not caused by insects was spread over a variety of factors. Animal damage, while not rare, seldom caused serious harm after the plantings were established. Two sample plantations on private land had been destroyed by sheep grazing soon after they were planted.

Little disease damage was noticed except for sweet fern rust cankers on jack pine branches particularly in the Mio area. Occasional damage by blister rust may not have been noted since only the most serious causal agent was recorded. Thus,

TABLE 10. - Damage in plantations of northern Lower Michigan by planted type and cause of damage, 1957

(In percent)

\begin{tabular}{|c|c|c|c|c|c|c|c|c|}
\hline \multirow[b]{2}{*}{$\begin{array}{l}\text { Planted } \\
\text { type }\end{array}$} & \multicolumn{4}{|c|}{ Without native overstories } & \multicolumn{4}{|c|}{ With native overstories } \\
\hline & $\begin{array}{c}\text { No } \\
\text { damage }\end{array}$ & Insect & Animal & Other 1 & $\begin{array}{c}\text { No } \\
\text { damage }\end{array}$ & Insect & Animal & Other ${ }^{1}$ \\
\hline White pine & 51 & 46 & - & 3 & 77 & 15 & - & 8 \\
\hline Red pine & 90 & 8 & - & 2 & 99 & - & - & 1 \\
\hline Jack pine & 80 & 19 & - & 1 & 94 & 5 & 1 & - \\
\hline Scotch pine ${ }^{2}$ & 75 & 20 & - & 5 & - & - & - & - \\
\hline White and red pine & 66 & 22 & - & 12 & 71 & 29 & - & - \\
\hline Red and jack pine & 68 & 30 & 1 & 1 & 76 & 14 & - & 10 \\
\hline White, red, and jack pine & 66 & 28 & 4 & 2 & 69 & 22 & 5 & 4 \\
\hline Spruce & 75 & 20 & - & 5 & 100 & - & - & - \\
\hline Miscellaneous conifers & 63 & 26 & - & 11 & 70 & - & - & 30 \\
\hline
\end{tabular}

1 Includes damage from fire, logging, ice, snow, frost, and drought, etc.

2 No samples were obtained in Scotch pine with native overstories. 


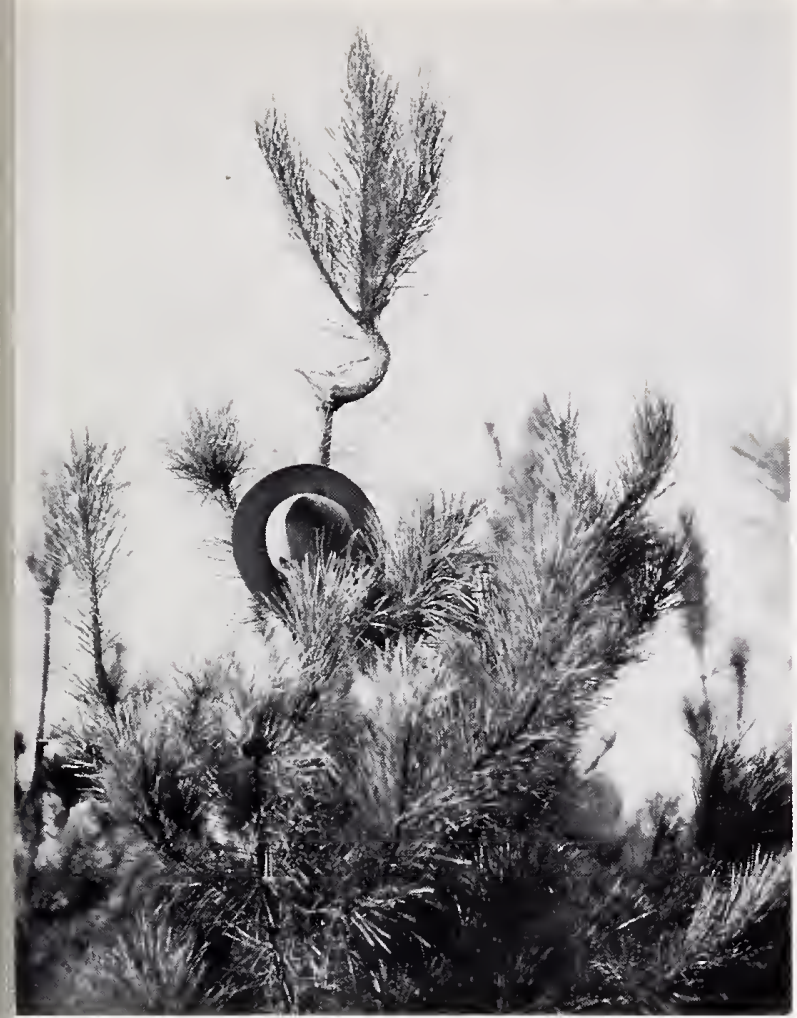

F-500772

Figure 22. - European pine shoot moth damage. This moth is one of the most damaging pests of red and Scotch pine in Michigan. While control remains difficult and expensive, intensive research studies are underway and show promise of controlling this threat to plantations.

where several white pine were weeviled and one or two infected with blister rust, the damage would have been recorded as weevil damage, the apparent major factor.

Climatic factors such as frost, wind, snow, ice, hail, and sleet accounted for about 4 percent of all damage to plantations.

Fire is a continual threat to plantations. Several serious fires have destroyed plantings. Since most of the trees are killed outright, the planting becomes a failure following fire. Thus, in young plantations fire is more serious as a killer than as a damager of trees. 


\section{CULTURAL TREATMENT}

In each sample plantation, the kind of past cultural treatment it had received and its present needs were recorded. These observations were summarized by species and kind of treatment (tables 11 and 12 ).

About 8 percent of all established plantings, or 42,000 acres, showed evidence of having received some kind of stand improvement. Release from competing native trees proved to be the most common treatment (fig. 23 ). Only 4 percent of the plantings presently without overstories had been released. Nearly 9 percent of the plantations with native tree overstories had also been released although significant overstories remained.

There were few apparent patterns of treatment by species except that white and red pine plantations, which would be more apt to be left to produce saw logs, had a higher proportion treated than the other species. About 1 acre in 8 of the Scotch pine area had been sheared for Christmas tree production; all of these were in plantings established after 1950.

According to the survey, release, thinning, or pruning is still needed on 147,000 plantation acres ( 28 percent). Because of the wide range of situations found in plantations and the limited knowledge about plantation management, the specifications for recommending treatment were based on current practice. (Pruning was recommended in stands with saw log potential; thinnings were recommended when 3 or more cords per acre could be removed in improving the residual stand; and release was recommended where overstory trees would support a commercial cut or amounted to over 40 percent of the crown cover.) About 18 percent of the plantations without native overstories and 46 percent of those with native overstories were recommended for treatment (table 11). Pruning is the major practice recommended in plantations without overstories (fig. 24), while release by killing or removing the native trees was recommended most often for plantings with native overstories. Although they occupy only 39 percent of the total plantation area, plantings with native overstories need 62 percent of the improvement work (table 11).

TABLE 11. - Stand improvement practices accomplished and needed in plantations of northern Lower Michigan, by kind of treatment

\begin{tabular}{|c|c|c|c|c|c|c|c|c|}
\hline \multirow{2}{*}{ Treatment } & \multicolumn{4}{|c|}{ Established area treated } & \multicolumn{4}{|c|}{ Established area needing treatment } \\
\hline & \multicolumn{2}{|c|}{ Without overstories } & \multicolumn{2}{|c|}{ With overstories } & \multicolumn{2}{|c|}{ Without overstories } & \multicolumn{2}{|c|}{ With overstories } \\
\hline & Acres & Percent & Acres & Percent & Acres & Percent & Acres & Percent \\
\hline Release & 12,000 & 4 & 17,900 & 9 & 12,000 & 4 & 81,700 & 41 \\
\hline Thinning & 8,700 & 3 & $1+$ & - & 14,400 & 5 & 900 & * \\
\hline Pruning & 3,200 & 1 & 200 & $*$ & 28,900 & 9 & 9,300 & 5 \\
\hline Total & 23,900 & 8 & 18,100 & 9 & 55,300 & 18 & 91,900 & 46 \\
\hline
\end{tabular}

Less than 0.5 percent.

TABLE 12. - Stand improvement practices accomplished and needed in plantations of northern Lower Michigan, by planted type

\begin{tabular}{|c|c|c|c|c|c|c|c|c|}
\hline \multirow{3}{*}{ Planted type } & \multicolumn{4}{|c|}{ Established area treated } & \multicolumn{4}{|c|}{ Established area needing treatment } \\
\hline & \multicolumn{2}{|c|}{ Without overstories } & \multicolumn{2}{|c|}{ With overstories } & \multicolumn{2}{|c|}{ Without overstories } & \multicolumn{2}{|c|}{ With overstories } \\
\hline & Acres & Percent & Acres & Percent & Acres & Percent & Acres & Percent \\
\hline White pine & 4,200 & 23 & 700 & 3 & 5,300 & 29 & 8,500 & 36 \\
\hline Red pine & 12,100 & 10 & 13,100 & 17 & 17,700 & 14 & 44,500 & 59 \\
\hline Jack pine & 1,800 & 4 & 2,400 & 15 & 6,500 & 16 & 7,100 & 45 \\
\hline Scotch pine & 2,800 & 10 & - & - & 2,000 & 7 & - & - \\
\hline White, red pine & 1,500 & 23 & 700 & 4 & 600 & 9 & 5,200 & 32 \\
\hline Red, jack pine & 500 & 1 & 900 & 1 & 19,200 & 25 & 24,400 & 40 \\
\hline White, red, jack & pine - & - & 200 & 3 & 1,800 & 32 & 1,300 & 20 \\
\hline Spruce & 1,000 & 12 & - & - & 1,100 & 13 & 600 & 43 \\
\hline Other & - & - & 100 & 10 & 1,100 & 18 & 300 & 24 \\
\hline Total & 23,900 & 8 & 18,100 & 9 & 55,300 & 18 & 91,900 & 46 \\
\hline
\end{tabular}


Figure 23. - Airplane spraying with silvicides kills low-value hardwoods, releasing conifer plantations. In $1960,10,800$ acres were released from competing hardwood on the Lower Michigan National Forest, largely by aerial spraying.

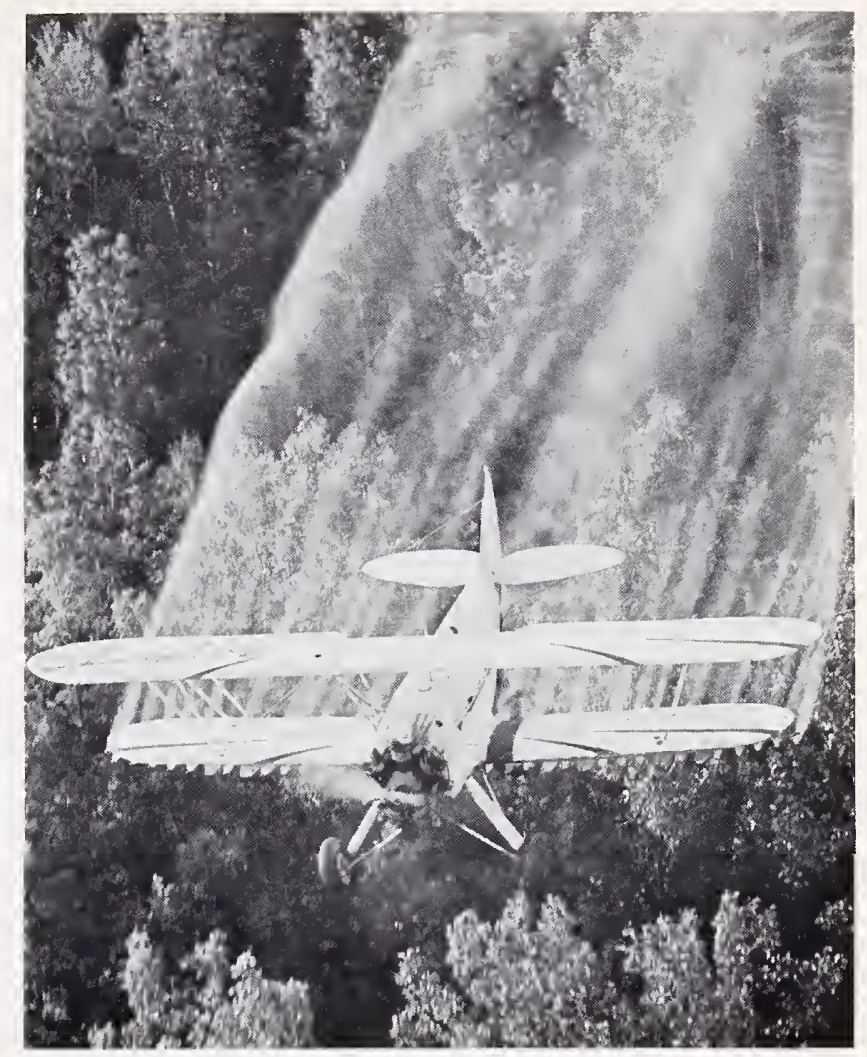

Figure 24. - A red pine plantation where pruning is needed to produce quality logs. (Photo courtesy of Consumers Power Company.)

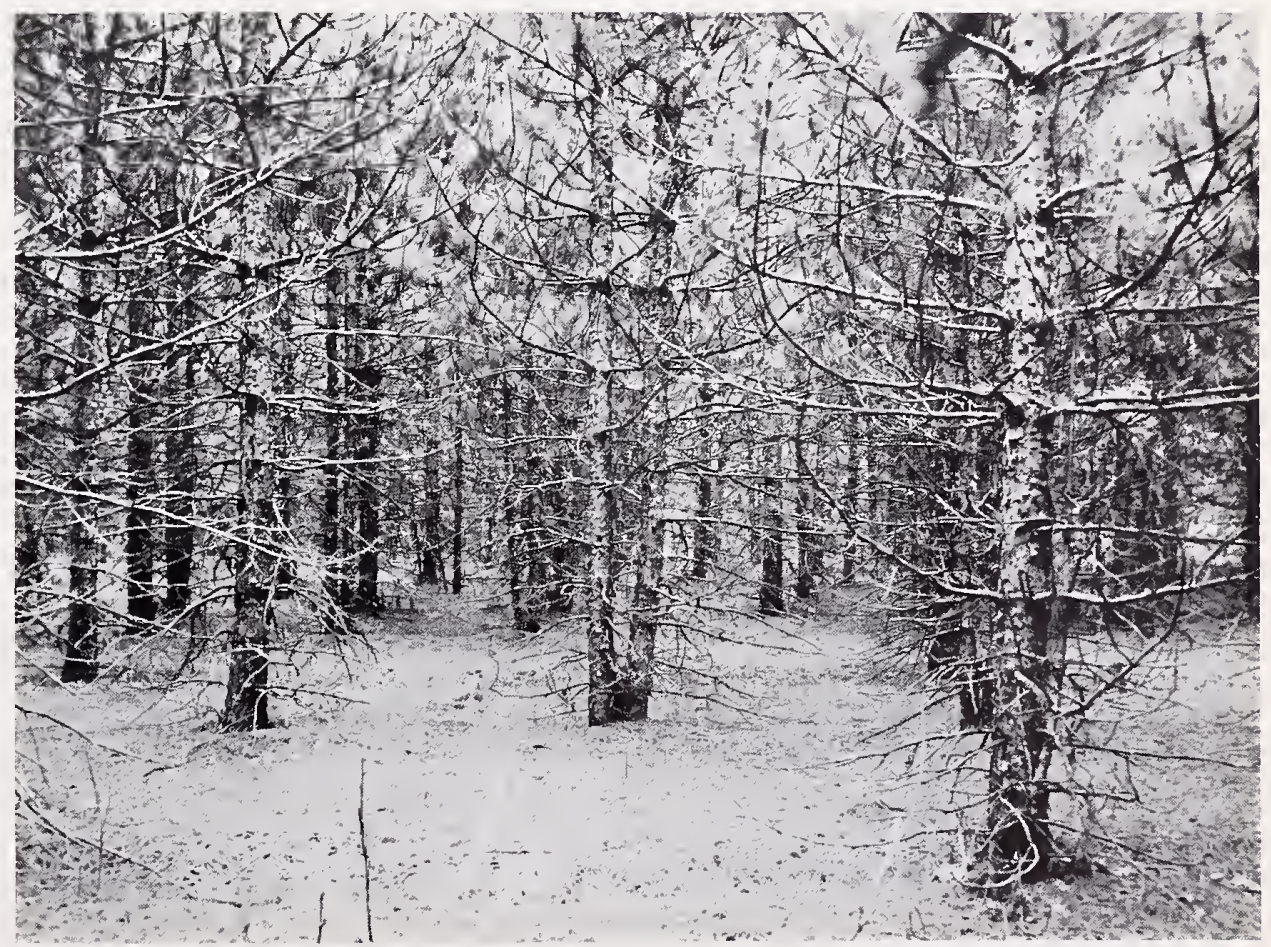




\section{SITE QUALITY OF PLANTED}

On plots with trees over 15 feet tall, the site index of a free-growing dominant planted tree nearest the plot center was determined as a measure of site quality. The total height of this tree was measured and the site rated by comparing its height and age with site index curves for that species. ${ }^{5}$ The site index curves available were developed for native stands. It is still unknown how applicable they are for plantations, which may have a significantly different height development pattern than their native counterparts.

For plantings shorter than 15 feet no attempt to classify site was made since the influence on height development was believed to be confounded with the influence of other factors (ground cover,

5 The site index curves used were prepared by S. $R$. Gevorkiantz during 1956 and 1957 and are available from the Lake States Forest Experiment Station, St. Paul, 1, Minnesota. They are Technical Notes 46.' (jack pine), 465 (balsam fir), $4 \pi 3$ (black sprace). $4 \pi_{4}$ (white spmece), 483 (white pine). and 484 (red pine).

\section{A REA}

quality of planting stock, planting methods, season of planting, etc.) so that height would not yield a valid estimate of site quality. Therefore, no site estimates were made for plots with no trees taller than 15 feet, those where the dominants were severely damaged, or where native trees overtopped the planted species. Site index measurements were made on 35 percent of the plots.

A wide variety of sites has been planted (fig. 25 ). The following tabulation presents average site index by planted type for plantings with and without native overstories:

Planted type

White pine

Red pine

Jack pine

Scotch pine

White, red pine

Red, jack pine

White, red, jack pine

Spruce

Other

1 Estimated height at 50 years.

\begin{tabular}{cc}
\multicolumn{2}{c}{$\begin{array}{c}\text { Average site index } \\
\text { of plantations - }\end{array}$} \\
\hline Without & With \\
overstories & overstories \\
62 & 49 \\
60 & 48 \\
55 & 55 \\
62 & - \\
48 & 44 \\
51 & 47 \\
52 & 49 \\
68 & - \\
58 & 45 \\
50 years. &
\end{tabular}

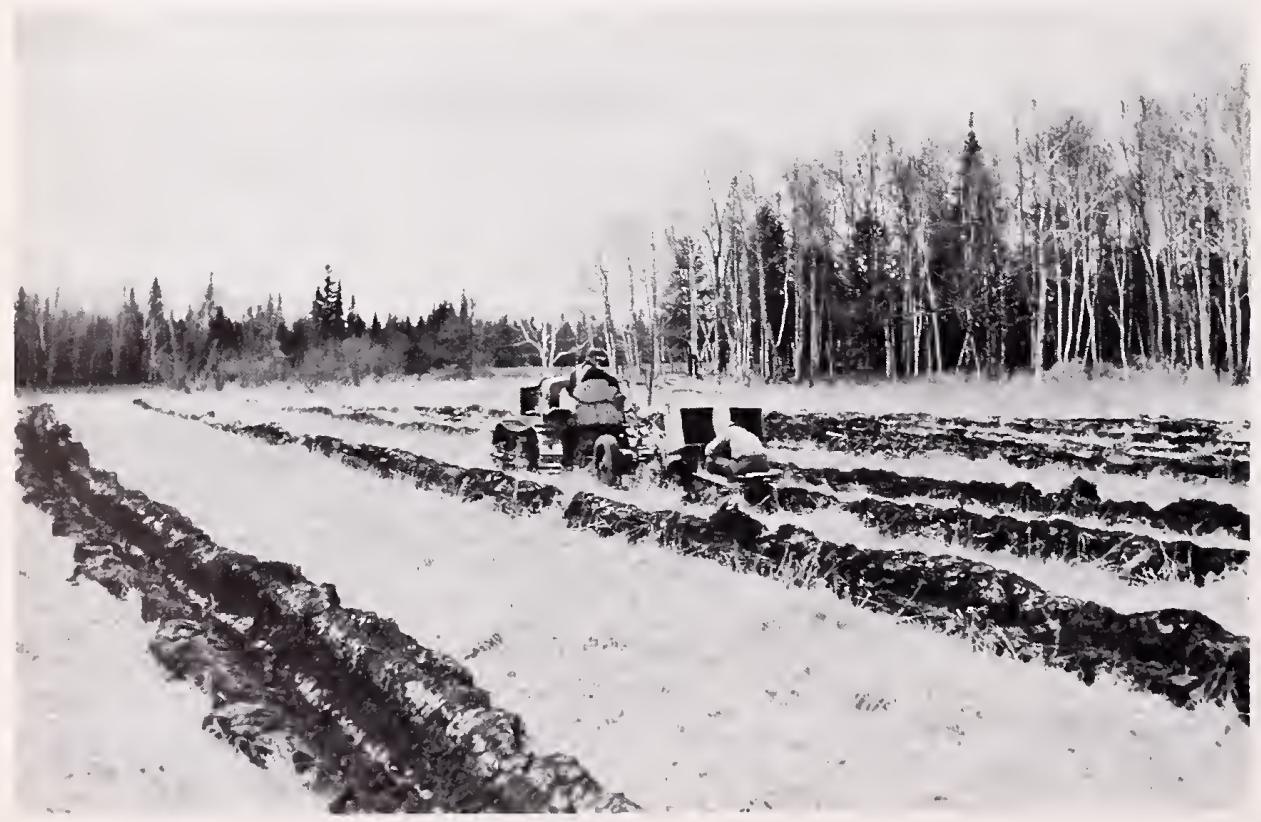

FiguRe 25. - Area vary ing from rich fertil fields to shallow sandy slopes have been reforested in northern Low er Michigan. (Phot courtesy of Consumer. Power Company.) 
The major difference in site index was between plantings of one species and mixed species plantings. The single species plantings occupy better sites, particularly spruce, white pine, and Scotch pine in plantings without overstories and jack pine with overstories. In plantings with native tree overstories the difference is slight. Apparently mixtures and less common species tend to be planted on problem areas.

The average site index of plantings with native overstories was below those without overstories for every type. This indicates that plantings with overstories have lower site quality since site trees in plantings with overstories were selected so as to avoid the effects of native tree competition. 


\section{SUMMARY AND CONCLUSIONS}

The plantations of northern Lower Michigan, while less than an unqualified success, constitute an impressive planting achievement. Through 1956 more than 660,000 acres had been reforested according to the results of this survey. Of this area about 78 percent or 517,000 acres rated as acceptable forest plantations. The 315,000 acres of acceptable plantations without native tree overstories make up about one-fifth of the conifer acreage in the district. These plantations are increasing in importance commercially, although yields are presently small because of the limited acreage that has developed far enough to sustain thinnings.

The condition of the plantations was found to vary widely in stocking level, volume, and degree of native tree competition. Earlier plantings were made with little experience, and have had indifferent or no treatment. Large areas are understocked and in poor growing condition. As a result the present volumes are much less than would be possible under management. Four out of every ten plantation acres are being suppressed by competing native trees. Early release will enlarge the conifer production from these stands. To date there is little available knowledge on possible yields from plantations although several outstanding plantations illustrate what might be achieved under more favorable conditions. A 29-year-old white pine plantation was sampled that contained more than 44 cords per acre. Several red pine plantings on the fertile benches along the Muskegon River contained about 30 cords at 27 to 29 years of age. This mean annual growth of over 1 cord per acre contrasts with growth of about one-third cord for all sampled red pine plantations. Similarly mean annual basal area growth was 2 to 3 square feet per acre in the plantations compared to 5 square feet on experimental areas at Higgins Lake.

Generally, the plantings occupy good sites, with the private plantations occurring more often on excellent sites than do the public plantings.

Improved management practices seem warranted in many plantings, particularly those on fine sites. Twenty-eight percent of the plantings presently need release, thinning, pruning, or a combination of these treatments to improve the quality and quantity of growth. On about 82,000 acres, native overstories mainly of low-value and poor-quality hardwoods are retarding plantation development.

Impressive as the planting achievements are, their final success will depend on the care the plantations receive as they mature. Their potential is high. The success obtained in getting conifers established on more than half a million acres can contribute much to the timber growth of northern Lower Michigan. 


\section{Definitions}

Commercial forest land area. - Forest land that is producing or physically capable of producing usable crops of wood and not withdrawn from timber utilization.

Forest types. - A forest type is characterized by the predominance of certain key species. Where no single species makes up 50 percent or more of the type the classification is based upon species with the majority volume or number.

White pine. - Fifty percent or more white pine.

Red pine. - Fifty percent or more red pine.

Jack pine. - Fifty percent or more jack pine.

Spruce. - Fifty percent or more white, black,

Norway, or blue spruce or any combination of the spruces.

Nonstocked (grass and brush). - Forest land having less than 10 percent of the growing space effectively used by trees. Includes upland and lowland brush and grass.

Planted type. - Type as of planting date.

White pine. - Fifty percent or more of the planted trees were white pine.

Red pine. - Fifty percent or more of the planted trees were red pine.

Jack pine. - Fifty percent or more of the planted trees were jack pine.

Scotch pine. - Fifty percent or more of the planted trees were Scotch pine.

White-red pine. - Mixed planting of white and red pine.

Red-jack pine. - Mixed planting of red and jack pine.

White, red, jack pine. - Mixed planting of white pine, red pine, and jack pine.

Spruce. - Fifty percent or more of the planted trees were spruce.

Other. - A planting of species other than the above making 50 percent or more of the trees planted.

Established forest plantation. - Plantations with 100 or more surviving planted trees per acre, larger than $2 \frac{1}{2}$ acres and 120 feet in width.

Native overstory. - Three or more cords of native tree volume per acre. (All unplanted trees were considered "native.")
Ownership. -

Private lands. - Lands under private control (includes small miscellaneous parcels of public land such as school and county forests, county parks, and Bankhead-Jones land ).

\section{Method Used to Determine Allowable Cut in Plantations from 1957-1966}

Allowable cut in plantations for the period 1957-1966 includes the volume that can be harvested from poletimber stands having 3 cords or more in excess of adequate growing stock. The standards for basal area to be left after thinning were established as 85 square feet for well-stocked poletimber, 75 square feet for medium-stocked poletimber, and 65 square feet for poorly stocked poletimber. These levels were arbitrarily selected for use in calculating allowable cut since what constitutes optimum growing stock in plantations remains to be clearly defined. Where some native trees were present the minimum cut of 3 cords included the thinnable volume of both the planted and native trees.

The allowable cut includes the cut on the thinnable stands at the beginning of the period plus improvement cuts on stands expected to move into merchantable size during the 10 -year period. The first year's allowable cut includes the total cuttable volume at the beginning of the period (or $\mathrm{CV}$ ) divided by $\mathrm{n}$ (years in the period). The second year's cut is the cuttable volume on stands reaching thinnable conditions the second year divided by $n$ in addition to the amount cut the first year. The third year's cut is the cuttable volume on stands reaching thinnable conditions the third year divided by $\mathrm{n}$ in addition to the amount cut the second year and the first year, and so on. The sum of the allowable cut for the 10-year period equals

$$
\mathrm{CV}+\frac{(\mathrm{n}-1)(\text { a.i. })}{2}
$$

where a.i. equals the annual increase in cuttable volume. The average annual cut is

$$
\frac{\mathrm{CV}+[0.5(\mathrm{n}-1)(\text { a.i. })]}{\mathrm{n}}
$$




\section{Accuracy}

Area. - Errors in estimating forest plantation acreage include (1) errors in area-planted summaries, (2) sampling errors, and ( 3 ) the amount of area planted and not detected by the survey. Since the area-planted estimates were based on record summaries, errors caused by mistakes in the records and in the summaries are possible. Acreage planted with trees from private nurseries shipped directly to planters and from transplanted wild trees are not included. Previous to World War II this acreage was believed to be of minor importance. However, since the war considerable acreages of Christmas trees, particularly red and Scotch pine and spruce, have been planted with stock from private nurseries. This area is not included in the forest plantation acreage, although part may remain for wood production. The sampling error depends on the number of samples taken. The sampling intensity was sufficient to provide an estimate of forest plantation area with a sampling error of 1.4 percent for the total established forest plantation area (one standard deviation ). This degree of accuracy was made possible by stratifying the samples by owner and decade.

Volume. - The sources of error in estimating plantation volume include errors in measurement of plot radius, tree diameter, and height, errors in volume tables, errors in collecting and computing plot data, and sampling errors (including area sampling error). The number of plots cruised in plantations was sufficient to provide a sampling error of 5.3 percent for the total volume (one standard deviation).

For any one owner, type, or county, area and volume sampling error is considerably higher. Generally, the smaller the area or volume, the higher the sampling error would be. The statistical accuracy of plantation area and volume is given below by owner group.

\begin{tabular}{lcccc}
$\begin{array}{c}\text { Owner } \\
\text { group }\end{array}$ & $\begin{array}{c}\text { Total area } \\
\text { (Thousand } \\
\text { acres) }\end{array}$ & $\begin{array}{c}\text { Area error } \\
\text { (Percent) }\end{array}$ & $\begin{array}{c}\text { Total volume } \\
\text { (Thousand } \\
\text { cords) }\end{array}$ & $\begin{array}{c}\text { Volume error } \\
\text { (Percent) }\end{array}$ \\
National forest & 204.4 & \pm 1.32 & 185.4 & \pm 10.11 \\
$\begin{array}{l}\text { State forest } \\
\text { Private }\end{array}$ & 158.2 & \pm 1.34 & 258.0 & \pm 5.12 \\
All owners & 154.3 & \pm 4.16 & 141.9 & \pm 13.53 \\
\hline
\end{tabular}

1 Sampling error at one standard deviation. 


\section{SOME RECENT STATION PAPERS LAKE STATES FOREST EXPERIMENT STATION}

Streambank Stabilization in Michigan - A Survey, by W. D. Striffler. Sta. Paper 84, 14 pp., illus. 1960.

Evaluating the Growth Potential of Aspen Lands in Northern Minnesota, by R. O. Strothmann. Sta. Paper 86, 20 pp., illus. 1960.

The Climatic Distribution of Blister Rust on White Pine in Wisconsin, by E. P. Van Arsdel, A. J. Riker, T. F. Kouba, V. E. Suomi, and R. A. Bryson. Sta. Paper 87, 34 pp., illus. 1961.

Forest Recreation in the Upper Great Lakes Area: Proceedings of a Seminar on Research Needs, May 11-13, 1961. Sta. Paper 89, 104 pp., illus. 1961.

Wisconsin's Forest Resources, by Robert N. Stone and Harry W. Thorne. Sta. Paper 90, 52 pp., illus. 1961.

Field Calibration of a Neutron-Scattering Soil Moisture Meter, by Richard S. Sartz and Willie R. Curtis. Sta. Paper 91, 15 pp., illus. 1961.

Growing White Pine in the Lake States to Avoid Blister Rust, by Eugene P. Van Arsdel. Sta. Paper 92, 11 pp., illus. 1961.

Farm Lumber Consumption and Use Data: Needs and Methods of Estimating, by Allen L. Lundgren and Ronald I. Beazley. Sta. Paper 93, 20 pp., illus. 1961.

Pulpwood Production in Lake States Counties, 1960, by Arthur G. Horn. Sta. Paper 94, 28 pp., illus. 1962.

Small Private Forest Landowners in Michigan's Upper Peninsula, by Dean N. Quinney. Sta. Paper 95, 20 pp., illus. 1962.

Contracting for Forest Aerial Photography in the United States, by Gene Avery and Merle P. Meyer. Sta. Paper 96, 37 pp., illus. 1962.

Three Pine Release Experiments in Northern Minnesota, by Robert E. Buckman and Allen L. Lundgren. Sta. Paper 97, 9 pp., illus. 1962.

Proceedings of the Fifth Lake States Forest Tree Improvement Conference. Sept. 19-20, 1961. Sta. Paper 98, 42 pp. (Processed.) 1961. 

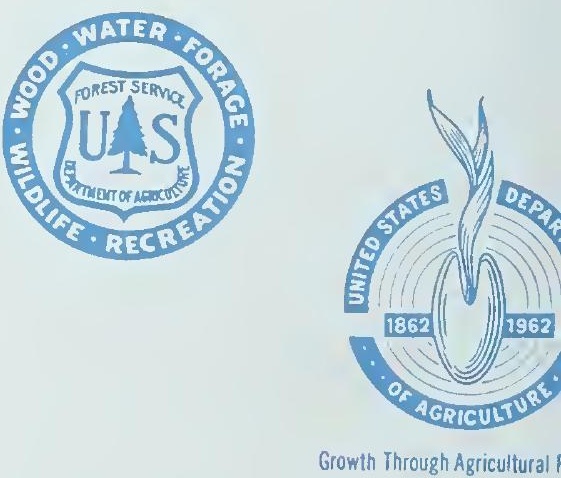